\title{
Investigating the Immune Function and Proteomic Profiles of Plasmal Exosomes in Lactobacillus Plantarum-treated Immunosuppressive Broilers
}

Huawei Liu

Qingdao Agriculture University: Qingdao Agricultural University

Fan Zhao

Qingdao Agricultural University

Kai Zhang

Qingdao Agriculture University: Qingdao Agricultural University

Jinshan Zhao

Qingdao Agriculture University: Qingdao Agricultural University

Yang Wang ( $\nabla$ yangwang@qau.edu.cn )

Qingdao Agriculture University: Qingdao Agricultural University

Research

Keywords: Lactobacillus plantarum, Broiler, Exosomes, Immunosuppression, Proteomic

Posted Date: June 22nd, 2021

DOl: https://doi.org/10.21203/rs.3.rs-612007/v1

License: (9) This work is licensed under a Creative Commons Attribution 4.0 International License.

Read Full License 


\section{Abstract}

Background: Exosomes are extracellular membranous nanovesicles that carry functional molecules, such as proteins, to mediate local and systemic cell-to-cell communication. Exosomes released by cells can present in the plasma and involved in the regulation of immunity. Probiotics play a beneficial role in improving the immune function of host through many mechanisms. However, whether probiotics can increase the immune function of broilers by regulating plasmal exosomal cargo is unclear.

Methods: Three hundred broilers were allocated to three treatments: control diet (CON group), control diet + dexamethasone (DEX) injection (DEX group), control diet containing $1 \times 10^{8} \mathrm{cfu} / \mathrm{g}$ Lactobacillus plantarum P8 + DEX injection (P8+DEX group). The immune function of broilers was detected by measuring the levels of inflammatory cytokines and immunoglobulins in plasma and jejunal mucosa. Exosomes were isolated from the plasma via EIQ3 isolation kits and characterized via transmission electron microscopy, nanoparticle tracking analysis, and Western blot. Then, exosomal protein profile was determined by proteomic. At last, correlation analysis was performed to figure out the potential role of exosomal proteins in regulating immune function of P8-treated broilers.

Results: P8+DEX treatment improved the immune function of DEX-induced immunosuppressive broiler through decreasing plasmal IL-1 $\beta$, IL-6, TNF- $\alpha$ and jejunal IL-1 $\beta$, as well as increasing plasmal IL-10 and jejunal IgM. The isolated extracellular vesicles had an average diameter of $125.8 \mathrm{~nm}$, exhibited a cupshaped morphology and expressed exosomal markers. A total of 784 proteins were identified in the exosomes. Among the 784 proteins, 126 differentially expressed proteins (DEPs) were found between DEX and CON groups, 102 DEPs were found between P8+DEX and DEX groups. Gene Ontology analysis indicated that DEPs between DEX and CON groups are mainly involved in metabolic process, cellular anatomical entity, cytoplasm, extracellular region and binding. DEPs between P8+DEX and DEX are mainly involved in multicellular organismal process, response to stimulus, cytoplasm, cell periphery, membrane, binding, protein binding and ion binding. Further, pathway analysis revealed that most of the DEPs between DEX and CON participated in the ECM-receptor interaction, focal adhesion, regulation of actin cytoskeleton, endocytosis and phagosome. Most of the DEPs between P8+DEX and DEX participated in the ErbB and PPAR signaling pathways. Moreover, many immunity-related DEPs were correlated with the altered immune parameters in plasma and jejunal in broilers fed with P8.

Conclusions: Our findings demonstrated that plasmal exosomes in immunosuppressive broilers fed with P8 carry proteins related to immune function, and may have immunomodulatory effects on the plasma and intestinal immunity.

\section{Background}

Stress-induced immunosuppression is a condition in which the immune system is affected by stress factors, and it can damage the immune organ cells and tissues, leading to abnormal immune function and the temporary or persistent dysfunction of the immune response [1, 2]. At present, stress-induced 
immunosuppression is a common condition in intensive breeding, especially in poultry breeding, resulting in serious threats to animal product food safety and public health $[3,4]$.

Exosomes are nanometer-sized (30-200 nm) membrane-enclosed extracellular vehicles $(E V s)[5,6]$ released from all cells that can enter into microenvironments and bloodstream [7]. Exosomes harbor a diverse of functional molecules (proteins, nuclear acids, and lipids) derived from their originating cells. This results in the formation of functionally diverse exosomes, capable of immune activation or immune suppression, respectively $[8,9]$. For example, B-lymphocyte-derived exosomes display abundant MHC Class I and II molecules, co-stimulatory molecules CD80 and CD86, adhesion molecule ICAM-1 (CD54), also $B$ cell marker CD20, and have the ability to activate CD4 + T cells in an antigen/MHC class II restricted way [10-12]. Tumor-derived exosomes cause time-dependent inhibition of the maturation of immature DCs via a dose-dependent, increased expression of IL-6 and phosphorylation of Stat 3 [13]. However, the role of exosomes in regulating broiler immunosuppression is little known.

Management of immunosuppression is complex. Under immunosuppression, the susceptibility of chickens to other bacterial and fungal infections enhanced [14]. Early usage of broad-spectrum antibiotics has achieved a significant reduction in the number of infections. However, there are problems resulting from the toxicity of these drugs and psychological decline [15]. Thus, finding safe immunepotentiating agents to improve the immune function in immunocompromised animals is important. Probiotics have been reported to improve the immune health status in immunocompromised animals or patients. For example, Lactobacillus strains protected mice from cyclophosphamide-caused myelosuppression and improved phagocytic cell recruitment to $C$. albicans infectious sites [15]. Lactobacillus rhamnosus GR-1 could lead to an increase in CD4 positive T cells and a decrease in febrile episodes in HIV patients [16]. Probiotics administration also reduced tumor incidence in Marek's disease virus-infected chickens [17]. Lactobacillus plantarum P8 (P8) is a probiotic strain isolated from the natural fermented yogurt of the Inner Mongolian herder's family. It is suggested that P8 could alleviate the hyperlipidemic of rat [18] and reduce the stress of adults [19]. Our previous study demonstrated that $1 \times 10^{8} \mathrm{cfu} / \mathrm{g}$ P8 inhibited oocyst shedding and elevated the growth performance as well as the intestinal health of broilers infected with Eimeria (data now shown). But whether P8 can improve the immune function and alter the exosomal composition of broilers under immunosuppression is unclear. Thus, in the present study, the levels of cytokines and immunoglobulins in the plasma and jejunal mucosa of dexamethasone sodium phosphate (DEX)-induced immunosuppressive broilers were measured, moreover, the quantitative proteomic analysis and potential biological functions of exosomal proteins were determined. In addition, correlation analysis was performed to figure out if the exosomal proteins paly a potential role in regulating the immune function of immunosuppressive broilers.

\section{Methods}

\section{Materials}


The probiotic P8 was purchased from Beijing SciTop Biotechnology Co., Ltd. (Beijing, China). The DEX injection was obtained from Beian Feilong Animal Pharmaceutical Factory (Heilongjiang, China).

\section{Birds and diets}

Three hundred one-day-old male Cobb broilers with similar initial body weights were purchased from Henan Academy of Agricultural Sciences. The basal diet was obtained from Henan Academy of Agricultural Sciences. The composition and nutrient levels of the basal diet is listed in Additional file 1 Table S1.

\section{Purity and identification checks of bacteria}

The culture and preparation of P8 was prepared by the Department of Animal Nutrition, Qingdao Agricultural University, China. P8 was cultured on Man Rogosa Sharpe media, kept at $37^{\circ} \mathrm{C}$ for $24 \mathrm{~h}$. Pure bacterial cells were collected after centrifugation at $5000 \times g$ for $10 \mathrm{~min}$ at $4{ }^{\circ} \mathrm{C}$. Then, these cells were washed twice with sterile $0.85 \%$ sodium chloride solution. Ultimately, the culture purity and identification were constantly checked by the spreading plate method [20].

\section{Experimental design}

A total of 300 broilers were equally divided into 4 treatments with 10 replicated cages of 10 birds each for a 21-day feeding period. The treatments were control diet (CON group), control diet + DEX intraperitoneal injection (DEX group), control diet containing $1 \times 10^{8} \mathrm{cfu} / \mathrm{g}$ P8 (P8 group), and control diet containing $1 \times$ $10^{8} \mathrm{cfu} / \mathrm{g}$ P8 + DEX intraperitoneal injection (P8+DEX group). At day 16, broilers in DEX and P8+DEX groups were injected with $3 \mathrm{mg} / \mathrm{Kg}$ BW DEX, while broilers in the CON and P8 groups were injected with equal volume of saline. Fresh water and feed were provided ad libitum. The temperature of the room was set at $33-35^{\circ} \mathrm{C}$ in the first week, and then decreased $2{ }^{\circ} \mathrm{C}$ every week until $24^{\circ} \mathrm{C}$.

\section{Sample collection}

At day 21 , blood samples from 1 broiler of each replicate were randomly collected by cardiac puncture into vacuum tubes containing anticoagulant and centrifuged for $10 \mathrm{~min}(3000 \times \mathrm{g})$ at $4{ }^{\circ} \mathrm{C}$. Pure plasma samples were collected and stored in $1.5 \mathrm{~mL}$ Eppendorf tubes at $-20^{\circ} \mathrm{C}$. The segments of jejunum from 1 broiler of each replicate were collected. Mucosa was scraped from $10 \mathrm{~cm}$ of the jejunum using a glass slide ( $5 \mathrm{~cm}$ proximal to the Meckel's diverticulum). Jejunal mucosa samples were placed immediately in liquid nitrogen and then held at $-80^{\circ} \mathrm{C}$.

\section{Analysis of biochemical indices}


The levels of immunoglobulin A (IgA), IgG, IgM, interleukin 6 (IL-6), IL-10, IL-1 $\beta$ and tumor necrosis factor a (TNF-a) in the plasma and jejunal mucosa were determined using ELISA kits (Shanghai Enzyme-linked Biotechnology Co., Ltd) according to manufacturer's protocol.

\section{Exosome Isolation}

Exosomes were isolated from plasmal samples by Exosome Isolation Q3 kit (EIQ3-02001, Wayen Biotechnologies, Shanghai, China). The frozen plasma samples were thawed in a $25{ }^{\circ} \mathrm{C}$ water bath and then placed on ice. Four microlitre Reagent $\mathrm{C}$ was added into $200 \mu \mathrm{L}$ plasma and mixed well by vortexing until obtain a homogenous mixture. The mixture was incubated at $37^{\circ} \mathrm{C}$ for $15 \mathrm{~min}$. After incubation, the samples turned into jellylibe status. The tubes were taped firmly to change the jellylibe status into liquid status and then centrifuged at $10000 \times \mathrm{g}$ for $10 \mathrm{~min}$ at room temperature. The supernatant was transferred into a new $1.5 \mathrm{~mL}$ tube and then placed on ice. Thereafter, $50 \mu \mathrm{L}$ Reagent $A$ was added in 200 $\mu \mathrm{L}$ pre-treated plasma and mixed. The mixture was incubated at $4{ }^{\circ} \mathrm{C}$ for $30 \mathrm{~min}$. After incubation, the supernatant was centrifuged at $3000 \times g$ for $10 \mathrm{~min}$ at room temperature. The pellet at the bottom of the tube was resuspended completely with $200 \mu \mathrm{L} 1 \times$ PBS and mixed well by vortexing until obtained a homogenous mixture. Fifty microlitre Reagent $\mathrm{B}$ was added into the re-suspension and mixed well by vortexing until obtained a homogenous mixture. The mixture was incubated at $4{ }^{\circ} \mathrm{C}$ for $30 \mathrm{~min}$. After incubation, the mixture was centrifuged at $3000 \times g$ for $10 \mathrm{~min}$ at room temperature. The exosomes pellet was obtained by removing the supernatant. The exosomes pellet completely in 50-120 $\mu \mathrm{L} 1 \times \mathrm{PBS}$ and mixed well to obtain a homogenous mixture. Once the pellet was re-suspended, the exosomes resuspension was aliquoted and stored at $-80^{\circ} \mathrm{C}$ till next experiments immediately.

\section{Exosomal protein extraction}

Exosomes samples were added the same value of protein lysis buffer (7 M Urea, $2 \%$ SDS) containing $1 \times$ protease inhibitor cocktail, followed by $1 \mathrm{~min}$ of sonication on ice using a ultrasonic processor (ultrasound on ice for $2 \mathrm{~s}$, stop for $5 \mathrm{~s}$ ), and rested on ice for $30 \mathrm{~min}$. The lysate was centrifuged at 13000 rpm for 20 min at $4{ }^{\circ} \mathrm{C}$, then the supernatant was transferred to a new $1.5 \mathrm{~mL}$ tube. Four times volume of $100 \%$ acetone was added and the mixture was precipitated overnight at $-20^{\circ} \mathrm{C}$. The sample solutions were centrifuged at the next day. The pellet at the bottom was collected and washed twice with $500 \mu \mathrm{L}$ pre-cooling washing buffer (ethanol: acetone: acetic acid $=50: 50: 0.1$ ). Finally, after centrifugation at $13000 \mathrm{rpm}$ for $15 \mathrm{~min}$ at $4{ }^{\circ} \mathrm{C}$, the precipitates were dissolved in buffer containing $6 \mathrm{M}$ guanidine hyfrochloride and $300 \mathrm{mM}$ TEAB, and the protein concentration was quantified with BCA assay.

\section{Transmission Electron Microscope (TEM)}

Five microlitre exosome sample was deposited on Formvar-carbon-coated copper grids for 5 min at room temperature. The excess liquid was removed using Whatman filter paper. Add a drop of $2 \%$ uranyl acetate and incubated for $1 \mathrm{~min}$ at room temperature. The excess liquid was removed using Whatman filter paper. After drying, samples were observed under a Tecnai G2 Spirit BioTwin TEM at $80 \mathrm{kV}$. The acquisitions were made with Gatan Orius SC200D camera. 


\section{Nanoparticle Tracking Analysis (NTA)}

The frozen exosomal samples were thawed in a $25^{\circ} \mathrm{C}$ water bath and then placed on ice. $1 \times$ PBS was used to dilute exosomes for NTA. NTA was performed using a NanoSight instrument (PARTICLE METRIX Malvern Panalytical, Ltd., Malvern, United Kingdom) with a $488 \mathrm{~nm}$ laser and automated syringe pump as previously described [21]. The ZetaView 8.04 .02 software was used to process the recorded movies.

\section{Western Blot Analysis (WB)}

Equal amounts of exosomal proteins from each group were subjected to SDS-PAGE, then proteins on the gel were transferred to nitrocellulose membrane. Membranes were blocked by $5 \%$ skimmed milk and then incubated with the primary antibodies (anti-CD63, anti-TSG101, and anti-Calnexin) overnight at $4{ }^{\circ} \mathrm{C}$. After washing with Tris Buffered Saline Tween, membranes were incubated with secondary antibody adjusted with Horseradish Peroxidase (Beyotime Biotechnology, China) [22].

\section{Filter aided proteome preparation}

Eighteen microgramme protein solution samples were taken from each sample, and the volume was determined to $100 \mu \mathrm{L}$ with $25 \mathrm{mM}$ ammonium bicarbonate. Then, $1 \mathrm{M}$ DTT was added (terminal concentration $20 \mathrm{mM}$ ) and incubated at $57 \circ \mathrm{C}$ for $1 \mathrm{~h}$. Then, $10 \mu \mathrm{L} 1 \mathrm{M}$ iodoacetamide was added (terminal concentration $90 \mathrm{mM}$ ) and incubated for 40 min at room temperature under dark conditions. The sample solution was centrifuged on a $10 \mathrm{kDa}$ ultrafiltration tube at 12,000 rpm, and dissolution buffer (ammonium bicarbonate) was added into the ultrafiltration tube to wash four times. The sample was digested with trypsin which was diluted with dissolution buffer at $37 \circ \mathrm{C}$ overnight. Next day the peptides were collected by centrifugation, and dried by centrifugal concentration.

\section{Desalination}

The dried peptides were desalted on a Monospin desalting column for mass spectrometry analysis. Dissolution the dried mixed peptide using $0.1 \%$ trifluoroacetic acid (TFA) solution. The $100 \%$ acetonitrile was used to activate the desalting column. Then, the $0.1 \%$ TFA solution was used to equilibrate the desalting column. The re-dissolved samples were added to the desalting column and centrifuged. Desalting column was cleaned using $0.1 \%$ TFA solution. Thereafter, $50 \%$ acetonitrile solution was added to collect the elution solution in a new tube. The elution solution was concentrated and dried by centrifugation to remove acetonitrile.

\section{Liquid Chromatography Tandem Mass Spectrometry (LC-MS)}

The dried samples were re-dissolved in $0.1 \%$ fluoroacetic acid (FA) solution and 1-2 $\mu$ g sample was taken for mass spectrometry analysis. The on-line Nano-RPLC liquid chromatography was performed by EasynLC 1000 system (Thermo Scientific, USA). The trap column was home-made C18 (C18, $5 \mu \mathrm{m}, 100 \mu \mathrm{m} * 2$ $\mathrm{cm})$ and the analytical column was $\mathrm{C} 18$ reversed-phase column $(\mathrm{C} 18,1.9 \mu \mathrm{m}, 75 \mu \mathrm{m} \times 200 \mathrm{~mm})$. The peptides results were subjected to nano electrospray ionization source followed by tandem mass 
spectrometry in Orbitrap Fusion Lumos (Thermo Scientific, USA). The mass spectrometer was operated in the data-dependent mode. For MS scans, the scan ranged from 350 to 1,600 m/z. Intact peptides were detected at a resolution of 60,000 and peptides were then selected for MS/MS at a resolution of 15,000. Collision energy: $30 \%$ HCD [21].

\section{Proteomic Analysis}

The MS/MS data were analyzed with MaxQuant software (version 1.5.8.3, Max-Planck Institute for Biochemistry, Germany), and proteins were identified by comparing the peptide spectra against the Swissprot databases. The Trypsin was specified as the cleavage enzyme, and up to two missed cleavages were allowed. The mass tolerance value for the fragment ions was set to $0.05 \mathrm{Da}$. The FDR was set to $<1 \%$. Proteins were quantified using label-free quantification, and the relative protein abundances are presented as the $\mathrm{mGC} / \mathrm{HC}$ ratios. The differential expression threshold was set to a 2fold change. Data analysis was contract service offered by Wayen Biotechnologies (Shanghai), Inc. (Shanghai, China).

\section{Statistical data analysis}

One-way ANOVA was used for single factor analysis by SPSS 20.0 for windows (SPSS Inc. Chicago, IL). Spearman's correlation coefficient was calculated using SPSS Version 20.0 (SPSS Inc., Chicago, IL) and GraphPad Prism 8 (GraphPad Software, Inc.) software and used to assess bivariate relationships between variables. Results were expressed as means and the differences were considered significant at $P<0.05$.

\section{Results}

\section{Effects of P8 on the levels of cytokines in the plasma and jejunal mucosa in broilers}

In the plasma, compared to the CON group, DEX significantly increased the level of IL-1 $\beta(P<0.01)$, and significantly decreased the level of IL-10 $(P<0.01)$. Besides, compared to the DEX treatment, P8+DEX led to lower levels of IL-1 $\beta(P<0.01)$, IL-6 $(P<0.05)$, TNF-a $(P<0.01)$, and higher level of IL-10 $(P<0.01)$ (Table 1).

In the jejunal mucosa, DEX significantly down-regulated the levels of IL-1 $\beta(P<0.01), \mathrm{IL}-6(P<0.05)$ and TNF-a $(P<0.05)$, and also up-regulated the level of IL-10 $(P<0.01)$ compared to the CON group. Additionally, broilers receiving P8+DEX had a decreased IL-1 $\beta$ level $(P<0.01)$ compared to the ones receiving DEX (Table 1$)$.

\section{Effects of P8 on the levels of immunoglobulins in the plasma and jejunal mucosa in broilers}

In the plasma, the levels of IgM, IgG and IgA were not altered significantly by different treatments. However, in the jejunal mucosa, DEX treatment led to a lower level of $\operatorname{IgM}(P<0.01)$, which was reversed 
by the treatment of P8+DEX $(P<0.01)$. But there were no significant differences of the IgG and IgA secretions among groups (Table 2 ).

\section{Characterization of exosomes}

The characterization of exosomes was performed by TEM, NTA and WB. TEM analysis demonstrated cup-shaped vesicles with a size range from 100-150 nm in diameter (Fig. 1A). NTA showed that the mean size of purified exosomes was $125.8 \pm 3.6 \mathrm{~nm}$, and the primary peak size was $129.3 \mathrm{~nm}$ (Fig. 1B). Moreover, WB analysis revealed that exosomal marker proteins (TSG101 and CD63) were obviously expressed in the exosome samples. However, calnexin, which generally represents contamination by intracellular proteins, was absent (Fig. 1C).

\section{Proteomic analysis of exosomes}

A total of 784 proteins were identified in plasma exosomes by label-free quantitative proteomic analysis, indicating that the exosomes contained abundant exosomal proteins (Additional file 1 Table S2).

Through exploration, we found that 126 differentially expressed proteins (DEPs) $(P<0.05)$ between DEX group and CON group were screened from the results based on the differential expression threshold (fold change $>2$ times) (Fig. 2). Among the 126 DEPs, 58 proteins were up-regulated (Table 3), while 68 proteins were down-regulated (Table 4) in plasmal exosomes isolated from broilers injected with DEX relative to those isolated from the control ones. Moreover, $102 \mathrm{DEPs}$ were screened between the exosomes from the P8+DEX group and DEX group (Fig. 2). Among the 102 DEPs, 40 proteins were upregulated (Table 5), while 62 proteins were down-regulated (Table 6) in plasmal exosomes isolated from broilers receiving P8+DEX relative to those isolated from broilers receiving DEX.

\section{Gene Ontology (GO) and Kyoto Encyclopedia of Genes and Genomes (KEGG) analyses of DEPs}

GO and KEGG analysis were conducted to understand the functional significance of DEPs. The results of GO enrichment analysis were classified into three sections: cellular component (CC), molecular function (MF), and biological process (BP). Compared to the CON group, DEPs in exosomes from the DEX group mainly participate in organic substance metabolic process (BP), nitrogen compound metabolic process (BP), macromolecule metabolic process (BP), cellular anatomical entity (CC), cytoplasm (CC), extracellular region (CC), binding (MF), protein binding (MF) and ion binding (MF) $(P<0.05)$ (Fig. 3). Furthermore, compared with the DEX group, DEPs in exosomes from the P8+DEX group mainly participate in multicellular organismal process (BP), response to stimulus (BP), cytoplasm (CC), cell periphery (CC), membrane (CC), binding (BP), protein binding (BP), ion binding (BP) $(P<0.05)$ (Fig. 3$)$.

KEGG pathway analysis showed that the enriched pathways within the DEPs between DEX and CON groups were mainly involved in ECM-receptor interaction (TNC/CD47), focal adhesion (PAK3/TNC/RAP1A/ZYX), regulation of actin cytoskeleton (PAK3/WASF2/RDX/ITGB2/BAIAP2), endocytosis (RABEP1/VPS37C/HSPA2/CHMP5/BF2/CHMP1A) and phagosome (ITGB2/BF2) $(P<0.05)$. In addition, the DEPs between P8+DEX and DEX groups were mainly involved in ErbB signaling 
(PAK3/KRAS/CAMK2D), PPAR signaling pathway (ILK/FABP6) and proteasome (PSMA5/PSMA3) $(P<$ 0.05) (Fig. 4, Additional file 1 Table S3 and S4).

\section{Correlation analysis between immune indices and proteomic of exosomes}

The correlation between immune indices and proteomic of exosomes was illustrated in Fig. 5 and Additional file 2 . Results with the correlation coefficient ( $r$ ) larger than 0.8 or less than -0.8 and the $P$ value less than 0.01 were selected. As for the plasmal indices, the IL-1 $\beta$ was negatively correlated with the protein under accession number A0A3Q2U3V9 $(r=-0.833, P<0.01)$ and positively correlated with the protein under accession number E1C007 (PACSIN2) $(r=0.817, P<0.01)$. IL-6 was positively correlated with the protein under accession number 093410 (CALM) $(r=0.800, P<0.01)$, F1NCZ2 (GDI1) ( $r=0.831$, $P<0.01)$ and Q04584 (ZYX) $(r=0.818, P<0.01)$. TNF-a was positively correlated with protein under accession number 093410 (CALM) $(r=0.817, P<0.01)$. IgA was negatively correlated with the protein under accession number A0A3Q2U775 $(r=-0.840, P<0.01)$ and F1NL81 (PI16) $(r=-0.803, P<0.01)$.

As for the jejunal mucosal indices, the IL-1 $\beta$ was negatively correlated with the protein under accession number F1NWN4 (FBLN2) $(r=-0.837, P<0.01)$, A0A3Q2U324 $(r=-0.800, P<0.01)$, F1P201 (VCAM1) $(r=$ -0.967, $P<0.01)$, A0A3Q2U775 ( $r=-0.857, P<0.01)$, R4GKL8 (C1QTNF3) $(r=-0.867, P<0.01)$, F1NPN5 (SPIA3) $(r=-0.837, P<0.01)$, Q90WD0 (ACTR3) $(r=-0.857, P<0.01)$, Q9DER4 (ZP1) $(r=-0.836, P<0.01)$, E1BUA6 (VNN1) $(r=-0.826, P<0.01)$, A0A3Q3AJD3 $(r=-0.900, P<0.01)$, and positively correlated with the protein under accession number A0A1L1RMF4 $(r=-0.803, P<0.01)$, Q9BD54 (CD74) $(r=-0.840, P<$ $0.01)$ and A0A3Q2TUM9 (C5AR1) $(r=-0.810, P<0.01)$. IL-10 was positively correlated with the protein under accession number A0A1D5P6B0 $(r=-0.857, P<0.01)$, A0A2H4C5L1 (BF) $(r=-0.857, P<0.01)$, A0A1L1RLL0 (RPL24) $(r=-0.865, P<0.01)$, F1NPS5 (CHMP1A) $(r=-0.884, P<0.01)$ and Q7T2X3 (LDLR) $(r=-0.898, P<0.01)$, and negatively correlated with the protein under accession number Q7T190 (TIMP3) $(r=-0.924, P<0.01)$. IgM was negatively correlated with the protein under accession number A0A3Q2U540 ( $r=-0.921, P<0.01)$, Q5W9C5 (BF1) $(r=-0.829, P<0.01)$, P35062 (HIST1H2A3) $(r=-0.829$, $P<0.01)$, E1C007 (PACSIN2) $(r=-0.979, P<0.01)$, A0A1L1RMF4 $(r=-0.824, P<0.01)$, R4GLT1 (CST3) $(r=$ $-0.835, P<0.01)$, A0A1D5PXM8 (VPS37C) $(r=-0.824, P<0.01)$, Q6PW00 (CD3D) $(r=-0.866, P<0.01)$, E1C3Y3 (TSPAN8) $(r=-0.834, P<0.01)$, F1NLE7 (AIMP1) $(r=-0.800, P<0.01)$, A0A1D5PMA3 (NELL2) $(r=$ $-0.840, P<0.01)$.

\section{Discussion}

In recent decades, more and more reports have proved the effective roles of exosomes involved in immunomodulation $[13,23,24]$. However, most of the research were done in human or murine models, little is known about the biofunction of exosomes in chickens. Limited reports on chicken exosomes have suggested that chicken biliary exosomes possess the capacity to influence the immune responses of lymphocytes and inhibit avian leukosis virus subgroup $J$ [25]. Polyinosinic-polycytidylic acid-stimulated exosomes from chicken macrophage cell line HD11 induced the NF-KB signaling pathway by phosphorylating TAK1 and NF-KB1 in HD11 and chicken T-cell line transformed by reticuloendotheliosis 
virus type T (REV-T) CU91 [26]. Exosomes of lipopolysaccharide-stimulated chicken macrophages modulated immune response through the MyD88/NF-KB signaling pathway [27]. Hence, the regulation of exosomes may be useful for improving the immune function of chickens.

Numerous reports demonstrated that probiotics can enhance the immune function of hosts through non immune mechanisms (stabilization of the gut mucosal barrier, competition for adhesion, secretion of antimicrobial substances, etc.) and the modulation of the mucosal and systemic immune responses [28]. A recent study also reported that the serum exosomes isolated from Lactobacillus plantarum No.14treated mice reduced in vitro cytokine production [29]. Thus, we hypothesized that probiotics may elevate the immune function of broilers through the circulating exosomes with functional biomolecules, such as proteins, lipids and nucleic acids.

In the present study, we used DEX to induce the immunosuppression of broilers [30] and we found that P8 could improve the immune function of DEX-treated broilers, reflected by the decreased plasmal IL-1 $\beta$, IL-6, TNF- $\alpha$ and jejunal IL-1 $\beta$, as well as the increased plasmal IL-10 and jejunal IgM. Then, we isolated exosomes from plasma samples by using EIQ3 exosome isolation kit. The isolated plasmal exosomes were identified by morphological observation and biochemical analysis. We observed that the ultrastructure and size of plasma exosomes complied with the typical morphology of exosomes [31, 32]. The surface markers of exosomes mainly included CD9, CD63, CD81, CD82, HSP27, HSP90, TSG101 and ALIX [33]. Here, the presence of exosomes was confirmed with the detection of CD63 and TSG101, and the purity of exosomes was confirmed by the absence of Calnexin.

In the past decades, the proteomic cargo of exosomes under immunosuppression have been investigated. Osteosarcoma exosomes contained immunosuppressive proteins including TGF- $\beta$, a fetoprotein and heat shock proteins [34]. Collagen type $V$ alpha 2 chain (COL5A2) and lipoprotein lipase (LPL) were significant higher in ovarian cancer cells derived exosomes than ovarian surface epithelial cells [35]. In the present study, proteomic analysis uncovered that a total of 784 proteins were present in plasmal exosomes. Out of the total 784 proteins, DEX induced 126 DEPs compared to the CON group, while P8 + DEX induced 102 DEPs compared to the DEX group. Unfortunately, no other studies using DEX or probiotics have reported data on exosomal proteomic to serve for comparison with our results. Further, we explored the general trends in functional changes of exosomal proteins identified in the present study via GO analysis. Most of the DEPs between DEX and CON groups were in the organic substance metabolic process, nitrogen compound metabolic process, cellular anatomical entity, binding, protein binding and ion binding. Besides, most of the DEPs between P8 + DEX and DEX were in the multicellular organismal process and response to stimulus, cytoplasm and binding, indicating their critical roles in the metabolism, stimulation and cell differentiation, yet their verifications merit further evaluating.

Furthermore, the proteins were analysed using KEGG database. DEPs between DEX and CON groups were mainly included in endocytosis (RABEP1/VPS37C/HSPA2/CHMP5/BF2/CHMP1A), phagosome (ITGB2/BF2) signaling pathway and so on, which might be involved in inflammation [36]. Besides, DEPs between P8 + DEX and DEX groups were mainly involved in ErbB signaling (PAK3/KRAS/CAMK2D), PPAR (ILK/FABP6) signaling pathway and so on. The ErbB signaling pathway is related to the development of 
cancer [37]. PAK3, KRAS and CAMK2D are genes involved in the ErbB signaling pathway. The decreased abundances of KRAS and CAMK2D in P8 + DEX group implied the attenuation of immunosuppression $[38,39]$. PAKs are important regulators of the inflammatory response. As reported by Taglieri et al. [40], only PAK1 and PAK2, but not PAK3, have been thus far associated with inflammation, immunity, and infective disease. Thus, the increased PAK3 expression in the present study may paly other biological roles rather than regulating the immunosuppression. Moreover, PPAR signaling pathway has antiinflammatory effects [41]. ILK and FABP6 are genes involved in the PPAR signaling pathway. The activation of PPAR upregulates ILK gene expression [42]. The elevated ILK abundance might indicate the decreased inflammation. In addition, FABP6 was high expressed in patients with cancer $[43,44]$. Hence, the decreased FABP6 level implied the alleviation of immunosuppression. This investigation offers insight into a potential role for circulating exosomes in regulation and function during immunosuppression.

To further confirm the effect of exosomal proteins on the immune function of broilers, the correlation analysis was performed between exosomal proteomic and immune parameters in plasma and jejunal mucosa. Among the DEPs that correlated with the immune parameters, we found that the expressions of protein E1C007 (PACSIN2), P35062 (HIST1H2A3), A0A1D5PMA3 (NELL2), A0A1L1RMF4, A0A3Q2U540, Q5W9C5 (BF1), R4GLT1 (CST3), E1C3Y3 (TSPAN8) and F1NLE7 (AIMP1) in the DEX group was higher than those of the CON and were lower than those of P8 + DEX group. Moreover, the expressions of protein R4GKL8 (C1QTNF3), Q9DER4 (ZP1), Q90WD0 (ACTR3) and A0A3Q2U3V9 in the DEX group were lower than those of the CON group and were higher than those of the P8 + DEX group. Reports have suggested that some of the aforementioned proteins, including E1C007 (PASCSIN2), A0A1D5PMA3 (NELL2), Q5W9C5 (BF1), R4GLT1 (CST3), E1C3Y3 (TSPAN8), were associated with the impairment of immune function, leading to immunosuppression [45-49], whereas, C1QTNF3 and ACTR3 were crucial for the normal immune function [50,51]. Results of the correlation analysis revealed that E1C007 was positively correlated with plasmal IL-1 $\beta$, and E1C007, A0A1D5PMA3, Q5W9C5, R4GLT1, E1C3Y3 as well as F1NLE7 were negatively correlated with jejunal IgM, besides, R4GKL8 and Q90WD0 was negatively correlated with the jejunal IL-1 $\beta$, indicating that the P8-induced plasmal exosomal proteins play an important role in improving the immune function of broilers.

\section{Conclusion}

In summary, we demonstrated that P8 effectively improved the immune function of DEX-induced immunosuppressive broilers. Moreover, a remarkable number of proteins involved in various biological processes, including ErbB and PPAR signalings are packed with plasmal exosomes from P8-treated immunosuppressive broilers. Correlation analysis indicated that the exosomal cargo of immunosuppressive broilers fed with P8 were involved in the improvement of immune function. These findings shed some light on the beneficial role of probiotic in regulating immune function of broilers through plasmal exosomal proteins. 


\section{Abbreviations}

P8: Lactobacillus plantarum P8; CON: control diet; DEX: dexamethasone; IL: interleukin; TNF-a: tumor necrosis factor; Ig: immunoglobulin; DEP: differentially expressed protein; WB: western blot; NTA: nanoparticle tracking analysis; TEM: transmission electron microscope; GO: gene ontology; KEGG: kyoto encyclopedia of genes and genomes.

\section{Declarations}

\section{Acknowledgements}

Not applicable.

\section{Authors' contributions}

HWL and YW designed the study. FZ and KZ performed the research; YW analyzed data and wrote the paper. JSZ and HWL contributed to revision of the manuscript. The authors read and approved the final manuscript.

\section{Consent for publication}

Not applicable.

\section{Competing interests}

The authors declare that there is no conflict of interest.

\section{Funding}

The authors would like to acknowledge the Natural Science Foundation of Shandong Provincial (ZR2020QC183), the Talents of High Level Scientific Research Foundation of Qingdao Agricultural University (Grant No. 663/1119042 and 6651119015), Qingdao Science and Technology Program (Grant No. 18-1-2-14-zhc) for financing this research.

\section{Availability of data and materials}

All the protein data are available via ProteomeXchange with identifier PXD026588.

\section{Ethics approval}

The animal experiment was approved and performed in accordance with the guidelines of Ethics and Animal Welfare Committee of Qingdao Agricultural University.

\section{References}


1. Shini S, Huff GR, Shini A, Kaiser P. Understanding stress-induced immunosuppression: exploration of cytokine and chemokine gene profiles in chicken peripheral leukocytes. Poult Sci. 2010;89(4):84151.

2. Zhao H, Wang Y, Shao Y, Liu J, Wang S, Xing M. Oxidative stress-induced skeletal muscle injury involves in NF-KB/p53-activated immunosuppression and apoptosis response in copper (II) or/and arsenite-exposed chicken. Chemosphere. 2018;210:76-84.

3. Kaboudi K. Virus-induced immunosuppression in turkeys (Meleagris gallopavo): A review. Open Vet J. 2020;9(4):349-60.

4. Guo Y, Su A, Tian H, Zhai M, Li W, Tian Y, et al. Transcriptomic analysis of spleen revealed mechanism of dexamethasone-induced immune suppression in chicks. Genes (Basel). 2020;11(5):513.

5. Pegtel DM, Gould SJ. Exosomes. Annu Rev Biochem. 2019;88:487-514.

6. Ding XQ, Wang ZY, Xia D, Wang RX, Pan XR, Tong JH. Proteomic profiling of serum exosomes from patients with metastatic gastric cancer. Front Oncol. 2020;10:1113.

7. Cumba Garcia LM, Peterson TE, Cepeda MA, Johnson AJ, Parney IF. Isolation and analysis of plasma-derived exosomes in patients with glioma. Front Oncol. 2019;9:651.

8. Théry C, Zitvogel L, Amigorena S. Exosomes: composition, biogenesis and function. Nat Rev Immunol. 2002;2(8):569-79.

9. Salimu J, Webber J, Gurney M, Al-Taei S, Clayton A, Tabi Z. Dominant immunosuppression of dendritic cell function by prostate-cancer-derived exosomes. J Extracell Vesicles. 2017;6(1):1368823.

10. Clayton A, Court J, Navabi H, Adams M, Mason MD, Hobot JA, et al. Analysis of antigen presenting cell derived exosomes, based on immuno-magnetic isolation and flow cytometry. J Immunol Methods. 2001;247(1-2):163-74.

11. Raposo G, Nijman HW, Stoorvogel W, Liejendekker R, Harding CV, Melief CJ, et al. B lymphocytes secrete antigen-presenting vesicles. J Exp Med. 1996;183(3):1161-72.

12. Li XB, Zhang ZR, Schluesener HJ, Xu SQ. Role of exosomes in immune regulation. J Cell Mol Med. 2006;10(2):364-75.

13. Yu S, Liu C, Su K, Wang J, Liu Y, Zhang L, et al. Tumor exosomes inhibit differentiation of bone marrow dendritic cells. J Immunol. 2007;178(11):6867-75.

14. Dey S, Pathak DC, Ramamurthy N, Maity HK, Chellappa MM. Infectious bursal disease virus in chickens: prevalence, impact, and management strategies. Vet Med (Auckl). 2019;10:85-97.

15. Salva S, Marranzino G, Villena J, Agüero G, Alvarez S. Probiotic Lactobacillus strains protect against myelosuppression and immunosuppression in cyclophosphamide-treated mice. Int Immunopharmacol. 2014;22(1):209-21.

16. Hummelen R, Vos AP, van't Land B, van Norren K, Reid G. Altered host-microbe interaction in HIV: a target for intervention with pro- and prebiotics. Int Rev Immunol. 2010;29(5):485-513. 
17. Bavananthasivam J, Alizadeh M, Astill J, Alqazlan N, Matsuyama-Kato A, Shojadoost B, et al. Effects of administration of probiotic lactobacilli on immunity conferred by the herpesvirus of turkeys vaccine against challenge with a very virulent Marek's disease virus in chickens. Vaccine. 2021;39(17):2424-33.

18. Bao Y, Wang Z, Zhang Y, Zhang J, Wang L, Dong X, et al. Effect of Lactobacillus plantarum P-8 on lipid metabolism in hyperlipidemic rat model. Eur J Lipid Sci Tech. 2012;114:1230-6.

19. Lew L, Hor Y, Yusoff NAA, Choi S, Yusoff MSB, Roslan NS, et al. Probiotic Lactobacillus plantarum P8 alleviated stress and anxiety while enhancing memory and congnition in stressed adults: A randomized, double-blind, placebo-controlled study. Clin Nutr. 2019;38:2053-64.

20. Nikoskelainen S, Ouwehand AC, Bylund G, Salminen S, Lilius EM. Immune enhancement in rainbow trout (Oncorhynchus mykiss) by potential probiotic bacteria (Lactobacillus rhamnosus). Fish Shellfish Immunol. 2003;15:443-52.

21. Song Z, Xu Y, Zhang L, Zhou L, Zhang Y, Han Y, et al. Comprehensive proteomic profiling of urinary exosomes and identification of potential non-invasive early biomarkers of Alzheimer's disease in 5XFAD mouse model. Front Genet. 2020;11:565479.

22. Wang Y, Wu Y, Wang Y, Fu A, Gong L, Li W, et al. Bacillus amyloliquefaciens SC06 alleviates the oxidative stress of IPEC-1 via modulating Nrf2/Keap1 signaling pathway and decreasing ROS production. Appl Microbiol Biot. 2017;101(7):3015-26.

23. Clayton A, Mitchell JP, Court J, Mason MD, Tabi Z. Human tumor-derived exosomes selectively impair lymphocyte responses to interleukin-2. Cancer Res. 2007;67(15):7458-66.

24. Liu J, Wu S, Zheng X, Zheng P, Fu Y, Wu C, et al. Immune suppressed tumor microenvironment by exosomes derived from gastric cancer cells via modulating immune functions. Sci Rep. 2020;10(1):14749.

25. Wang $Y$, Wang G, Wang Z, Zhang H, Zhang L, Cheng Z. Chicken biliary exosomes enhance CD4(+)T proliferation and inhibit ALV-J replication in liver. Biochem Cell Biol. 2014;92(2):145-51.

26. Hong Y, Lee J, Vu TH, Lee S, Lillehoj HS, Hong YH. Immunomodulatory effects of poly(I:C)-stimulated exosomes derived from chicken macrophages. Poult Sci, 2021. In Press.

27. Hong Y, Lee J, Vu TH, Lee S, Lillehoj HS, Hong YH. Exosomes of lipopolysaccharide-stimulated chicken macrophages modulate immune response through the MyD88/NF-KB signaling pathway. Dev Comp Immunol. 2021;115:103908.

28. Castillo NA, Leblanc ADMD, Galdeano CM. G Perdigón. Probiotics: An alternative strategy for combating salmonellosis. Food Res Int. 2012;45(2):831-41.

29. Aoki-Yoshida A, Saito S, Tsuruta T, Ohsumi A, Tsunoda H, Sonoyama K. Exosomes isolated from sera of mice fed Lactobacillus strains affect inflammatory cytokine production in macrophages in vitro. Biochem Biophys Res Commun. 2017;489(2):248-54.

30. Giles AJ, Hutchinson MND, Sonnemann HM, Jung J, Fecci PE, Ratnam NM, et al. Dexamethasoneinduced immunosuppression: mechanisms and implications for immunotherapy. J Immunother Cancer. 2018;6(1):51. 
31. Dear JW, Street JM, Bailey MA. Urinary exosomes: a reservoir for biomarker discovery and potential mediators of intrarenal signaling. Proteomics. 2013;13(10-11):1572-80.

32. Colombo M, Raposo G, Théry C. Biogenesis, secretion, and intercellular interactions of exosomes and other extracellular vesicles. Annu Rev Cell Dev Biol. 2014;30:255-89.

33. Jiao YJ, Jin DD, Jiang F, Liu JX, Qu LS, Ni WK, et al. Characterization and proteomic profiling of pancreatic cancer-derived serum exosomes. J Cell Biochem. 2019;120(1):988-99.

34. Troyer RM, Ruby CE, Goodall CP, Yang L, Maier CS, Albarqi HA, et al. Exosomes from Osteosarcoma and normal osteoblast differ in proteomic cargo and immunomodulatory effects on T cells. Exp Cell Res. 2017;358(2):369-76.

35. Cheng L, Zhang K, Qing Y, Li D, Cui M, Jin P, et al. Proteomic and lipidomic analysis of exosomes derived from ovarian cancer cells and ovarian surface epithelial cells. J Ovarian Res. 2020;13(1):9.

36. Vergne I, Gilleron M, Nigou J. Manipulation of the endocytic pathway and phagocyte functions by Mycobacterium tuberculosis lipoarabinomannan. Front Cell Infect Microbiol. 2015;4:187.

37. Olayioye MA, Neve RM, Lane HA, Hynes NE. The ErbB signaling network: receptor heterodimerization in development and cancer. EMBO J. 2000;19(13):3159-67.

38. Björn K, Tiziana M, Sarah N, Andreas H, Emma K, Colin N.et al. The ERBB network facilitates KRASdriven lung tumorigenesis. Sci Transl Med. 2018;10(446):96.

39. Kim S. A new computational approach to evaluating systemic gene-gene interactions in a pathway affected by drug LY294002. Processes. 2020;8(10):1230.

40. Taglieri DM, Ushio-Fukai M, Monasky MM. P21-activated kinase in inflammatory and cardiovascular disease. Cell Signal. 2014;26(9):2060-9.

41. Liu Y, Colby JK, Zuo X, Jaoude J, Wei D, Shureiqi I. The role of PPAR- $\delta$ in metabolism, inflammation, and cancer: many characters of a critical transcription factor. Int J Mol Sci. 2018;19(11):3339.

42. Tachibana K, Yamasaki D, Ishimoto K, Doi T. The role of PPARs in cancer. PPAR Res. 2008;2008:102737.

43. Ohmachi T, Inoue H, Mimori K, Tanaka F, Sasaki A, Kanda T, et al. Fatty acid binding protein 6 is overexpressed in colorectal cancer. Clin Cancer Res. 2006;12(17):5090-5.

44. Zhang Y, Zhao X, Deng L, Li X, Wang G, Li Y, et al. High expression of FABP4 and FABP6 in patients with colorectal cancer. World J Surg Oncol. 2019;17(1):171.

45. Popov S, Popova E, Inoue M, Wu Y, Göttlinger H. HIV-1 gag recruits PACSIN2 to promote virus spreading. Proc Natl Acad Sci U S A. 2018;115(27):7093-8.

46. Kim DH, Roh YG, Lee HH, Lee SY, Kim SI, Lee BJ, et al. The E2F1 oncogene transcriptionally regulates NELL2 in cancer cells. DNA Cell Biol. 2013;32(9):517-23.

47. Kim T, Hunt HD, Parcells MS, van Santen V, Ewald SJ. Two class I genes of the chicken MHC have different functions: BF1 is recognized by NK cells while BF2 is recognized by CTLs. Immunogenetics. 2018;70(9):599-611. 
48. Yan Y, Fan Q, Wang L, Zhou Y, Li J, Zhou K. LncRNA Snhg1, a non-degradable sponge for miR-338, promotes expression of proto-oncogene CST3 in primary esophageal cancer cells. Oncotarget. 2017;8(22):35750-60.

49. Zhao K, Wang Z, Hackert T, Pitzer C, Zöller M. Tspan8 and Tspan8/CD151 knockout mice unravel the contribution of tumor and host exosomes to tumor progression. J Exp Clin Cancer Res. 2018;37(1):312.

50. Murayama MA, Kakuta S, Maruhashi T, Shimizu K, Seno A, Kubo S, et al. CTRP3 plays an important role in the development of collagen-induced arthritis in mice. Biochem Biophys Res Commun. 2014;443(1):42-8.

51. Bolger-Munro M, Choi K, Scurll JM, Abraham L, Chappell RS, Sheen D, et al. Arp2/3 complex-driven spatial patterning of the BCR enhances immune synapse formation, BCR signaling and B cell activation. Elife. 2019;3:8:e44574.

\section{Tables}

Table 1 Effects of P8 on the levels of cytokines in the plasma and jejunal mucosa of broilers

\begin{tabular}{|llllll|}
\hline Item & CON & DEX & P8+DEX & SEM & $P$-value \\
\hline Plasma & & & & & \\
\hline IL-1 $\beta(\mathrm{ng} / \mathrm{L})$ & $89.67^{\mathrm{b}}$ & $108.12^{\mathrm{a}}$ & $85.00^{\mathrm{b}}$ & 6.23 & 0.004 \\
\hline IL-6 (ng/L) & $38.76^{\mathrm{ab}}$ & $40.10^{\mathrm{a}}$ & $30.73^{\mathrm{c}}$ & 3.55 & 0.032 \\
\hline TNF-a (ng/L) & $55.94^{\mathrm{ab}}$ & $62.00^{\mathrm{a}}$ & $46.30^{\mathrm{c}}$ & 3.81 & 0.001 \\
\hline IL-10 (ng/L) & $39.81^{\mathrm{ab}}$ & $29.16^{\mathrm{c}}$ & $35.45^{\mathrm{b}}$ & 2.56 & 0.000 \\
\hline Jejunal mucosa & & & & & \\
\hline IL-1 $\beta(\mathrm{ng} / \mathrm{mg})$ & $141.51^{\mathrm{b}}$ & $154.71^{\mathrm{a}}$ & $138.58^{\mathrm{b}}$ & 4.06 & 0.000 \\
\hline IL-6 (ng/mg) & $31.78^{\mathrm{b}}$ & $40.47^{\mathrm{a}}$ & $35.63^{\mathrm{ab}}$ & 3.71 & 0.040 \\
\hline TNF-a (ng/mg) & $62.50^{\mathrm{b}}$ & $69.98^{\mathrm{a}}$ & $63.78^{\mathrm{ab}}$ & 3.37 & 0.012 \\
\hline IL-10 (ng/mg) & $55.66^{\mathrm{a}}$ & $39.71^{\mathrm{b}}$ & $44.34^{\mathrm{b}}$ & 2.65 & 0.000 \\
\hline
\end{tabular}

a,b,c Mean value within a role with no common superscript differ significantly $(P<0.05)$. CON, control diet; DEX, control diet + DEX injection; P8, control diet containing $1 \times 10^{8} \mathrm{cfu} / \mathrm{g} \mathrm{P} 8$; P8+DEX, control diet containing $1 \times 10^{8} \mathrm{cfu} / \mathrm{g}$ P8 + DEX injection

Table 2 Effects of P8 on the levels of immunoglobulins in the plasma and jejunal mucosa of broilers 


\begin{tabular}{|c|c|c|c|c|c|}
\hline Item & $\mathrm{CON}$ & DEX & P8+DEX & SEM & $P$-value \\
\hline \multicolumn{6}{|l|}{ Plasma } \\
\hline $\lg M(n g / m L)$ & 290.25 & 283.16 & 239.00 & 32.29 & 0.406 \\
\hline $\lg G(\mu \mathrm{g} / \mathrm{mL})$ & 3.46 & 4.54 & 3.78 & 0.61 & 0.352 \\
\hline $\lg A(n g / m L)$ & 727.25 & 827.25 & 716.63 & 73.79 & 0.441 \\
\hline \multicolumn{6}{|c|}{ Jejunal mucosa } \\
\hline $\operatorname{lgM}(\mathrm{ng} / \mathrm{mg})$ & $584.42^{a}$ & $371.92^{b}$ & $556.92^{a}$ & 57.34 & 0.001 \\
\hline $\operatorname{lgG}(\mathrm{ng} / \mathrm{mg})$ & 6.24 & 5.92 & 4.30 & 0.74 & 0.058 \\
\hline $\lg A(n g / m g)$ & 914.75 & 809.75 & 901.63 & 68.88 & 0.341 \\
\hline
\end{tabular}

a,b Mean value within a role with no common superscript differ significantly $(P<0.05)$. CON, control diet; DEX, control diet + DEX injection; P8, control diet containing $1 \times 10^{8} \mathrm{cfu} / \mathrm{g}$ P8; P8+DEX, control diet containing $1 \times 10^{8} \mathrm{cfu} / \mathrm{g}$ P8 + DEX injection

Table 3 The up-regulated DEPs between DEX and CON groups 


\begin{tabular}{|c|c|c|c|c|c|}
\hline Accession & Description & Gene symbol & $\begin{array}{l}\text { Unique } \\
\text { peptides }\end{array}$ & $\begin{array}{l}\text { DEX vs } \\
\text { CON } \\
\text { (ratio) }\end{array}$ & $\begin{array}{l}\text { DEX } \\
\text { VS } \\
\text { CON } \\
(P- \\
\text { value })\end{array}$ \\
\hline P35062 & Histone H2A-III & $\begin{array}{l}\text { HIST1H2A3; } \\
\text { LOC427881; } \\
\text { HIST1H2A4L3; } \\
\text { LOC417955 }\end{array}$ & 2 & 64.54129 & 0 \\
\hline F1NIW7 & Cubilin & CUBN & 4 & 20.68636 & 0 \\
\hline A0A3Q2UFJ3 & $\begin{array}{l}\text { Calcium/calmodulin- } \\
\text { dependent protein kinase }\end{array}$ & CAMK2D & 3 & 19.65484 & 0 \\
\hline F1NBT0 & $\begin{array}{l}\text { Serine/threonine-protein } \\
\text { kinase } 10\end{array}$ & STK10 & 5 & 13.74323 & 0.0323 \\
\hline Q7T190 & $\begin{array}{l}\text { Tissue inhibitor of } \\
\text { metalloproteinase } 3 \\
\text { (Fragment) }\end{array}$ & TIMP3 & 1 & 13.6144 & 0.0238 \\
\hline A0A3Q2TX84 & $\begin{array}{l}\text { Ig-like domain-containing } \\
\text { protein }\end{array}$ & - & 1 & 11.68156 & 0.0183 \\
\hline A0A3Q2TUE5 & $\begin{array}{l}\text { Ig-like domain-containing } \\
\text { protein }\end{array}$ & - & 2 & 11.43221 & 0.0362 \\
\hline F1NUJ7 & $\begin{array}{l}\text { FABP domain-containing } \\
\text { protein }\end{array}$ & FABP6 & 2 & 9.59988 & 0 \\
\hline A0A3Q2UIJ5 & Uncharacterized protein & LOC769729 & 1 & 9.57246 & 0 \\
\hline A0A1D5PMA3 & Uncharacterized protein & NELL2 & 1 & 8.64332 & 0.0119 \\
\hline A0A1D5PY04 & $\begin{array}{l}\text { Uncharacterized protein } \\
\text { protein }\end{array}$ & CLIP2 & 2 & 8.4481 & 0.0354 \\
\hline A0A1D5NTE7 & $\begin{array}{l}\text { Fibrinogen C-terminal } \\
\text { domain-containing } \\
\text { protein }\end{array}$ & - & 2 & 7.76389 & 0.0476 \\
\hline A0A3Q2TXS3 & $\begin{array}{l}\text { Ig-like domain-containing } \\
\text { protein }\end{array}$ & - & 1 & 7.54106 & 0 \\
\hline A0A3Q2TXN1 & Uncharacterized protein & - & 4 & 6.04833 & 0.0079 \\
\hline A0A3Q3АРB3 & Uncharacterized protein & LOC101748084 & 1 & 5.86691 & 0 \\
\hline A0A1D5PGD5 & $\begin{array}{l}\text { Collagen alpha-3 (VI) } \\
\text { chain }\end{array}$ & COL6A3 & 10 & 5.72437 & 0.0207 \\
\hline A0A1D5PKY9 & Septin & SEPT6 & 2 & 5.21007 & 0.0151 \\
\hline F1NEB3 & Uncharacterized protein & HABP2 & 5 & 5.04958 & 0.0013 \\
\hline Q5F3I1 & Fibrinogen C-terminal & FGL2 & 3 & 4.76188 & 0.0006 \\
\hline
\end{tabular}


domain-containing

protein

\begin{tabular}{|c|c|c|c|c|c|}
\hline A0A3Q2U540 & $\begin{array}{l}\text { Ig-like domain-containing } \\
\text { protein }\end{array}$ & - & 2 & 4.55025 & 0.0134 \\
\hline Q5F442 & Uncharacterized protein & RASA3 & 1 & 4.51919 & 0 \\
\hline F1NBW3 & Serine incorporator 5 & SERINC5 & 1 & 4.51106 & 0.0294 \\
\hline A0A3Q2U4V6 & $\begin{array}{l}\text { Ig-like domain-containing } \\
\text { protein }\end{array}$ & - & 1 & 4.41341 & 0.0005 \\
\hline P21760 & $\begin{array}{l}\text { Extracellular fatty acid- } \\
\text { binding protein }\end{array}$ & $\begin{array}{l}\text { LCN8; P20K; } \\
\text { LCN15; EXFABP }\end{array}$ & 2 & 4.01483 & 0.0015 \\
\hline Q27J90 & $\begin{array}{l}\text { Leukocyte ribonuclease A- } \\
2\end{array}$ & RSFR & 2 & 3.91679 & 0.0033 \\
\hline Q5ZKY7 & Tetraspanin & CD82 & 3 & 3.85704 & 0.037 \\
\hline F1C6X7 & $\begin{array}{l}\text { MHC class II antigen } \\
\text { alpha chain }\end{array}$ & $\begin{array}{l}\text { B-LA; BLA; HLA- } \\
\text { DRA }\end{array}$ & 2 & 3.78031 & 0.0111 \\
\hline A0A3Q2UDP3 & $\begin{array}{l}\text { Uncharacterized protein } \\
\text { OS=Gallus gallus } \\
O X=9031 \mathrm{GN}=\mathrm{DOCK} 10 \\
\mathrm{PE}=3 \mathrm{SV}=1\end{array}$ & DOCK10 & 2 & 3.66783 & 0.0004 \\
\hline F1NV09 & $\begin{array}{l}\text { Epithelial cell adhesion } \\
\text { molecule }\end{array}$ & EPCAM & 4 & 3.66275 & 0.0001 \\
\hline A0A1D5PH32 & $\begin{array}{l}\text { Actin-depolymerizing } \\
\text { factor }\end{array}$ & GSN & 3 & 3.52032 & 0.0378 \\
\hline Q90593 & $\begin{array}{l}\text { Endoplasmic reticulum } \\
\text { chaperone } \mathrm{BiP}\end{array}$ & HSPA5 & 3 & 3.42985 & 0.0005 \\
\hline F1NW23 & Clathrin heavy chain & CLTC & 12 & 3.27741 & 0.0426 \\
\hline Q6IEC5 & Putative ISG12(2) protein & ISG12-2; IFI6 & 5 & 3.19787 & 0.0203 \\
\hline E1C3Y3 & $\begin{array}{l}\text { Tetraspanin OS=Gallus } \\
\text { gallus OX=9031 } \\
\mathrm{GN}=\mathrm{TSPAN} 8 \mathrm{PE}=3 \mathrm{SV}=2\end{array}$ & TSPAN8 & 1 & 3.05368 & 0 \\
\hline A0A3Q2U871 & Uncharacterized protein & - & 7 & 3.00759 & 0.049 \\
\hline P26007 & Integrin alpha-6 & ITGA6 & 6 & 2.87969 & 0.0326 \\
\hline Q2MJT5 & Glycoprotein IIIb & CD36 & 2 & 2.80456 & 0.0445 \\
\hline R4GLT1 & $\begin{array}{l}\text { Cystatin domain- } \\
\text { containing protein }\end{array}$ & CST3 & 1 & 2.7426 & 0 \\
\hline A0A1D5PT95 & Uncharacterized protein & KRAS & 1 & 2.68849 & 0.0117 \\
\hline A0A1D5P4G6 & Integrin alpha-V & ITGAV & 8 & 2.6846 & 0.0478 \\
\hline
\end{tabular}




\begin{tabular}{|c|c|c|c|c|c|}
\hline Q5W9C5 & MHC class I antigen & BF1; HFE & 1 & 2.67921 & 0 \\
\hline Q5F3U5 & Uncharacterized protein & RAP2C & 2 & 2.57332 & 0.0043 \\
\hline F1P4U3 & $\begin{array}{l}\text { Secreted phosphoprotein } \\
2\end{array}$ & SPP2 & 1 & 2.44087 & 0.0006 \\
\hline F1NDH2 & Angiotensin 1-10 & AGT & 5 & 2.39932 & 0.0412 \\
\hline E1C007 & $\begin{array}{l}\text { Protein kinase } C \text { and } \\
\text { casein kinase substrate in } \\
\text { neurons protein } 2\end{array}$ & PACSIN2 & 3 & 2.37931 & 0.0221 \\
\hline E1COF3 & Uncharacterized protein & RAB7A & 1 & 2.2642 & 0.0003 \\
\hline A0A3Q2TZ57 & $\begin{array}{l}\text { Ig-like domain-containing } \\
\text { protein }\end{array}$ & - & 1 & 2.10007 & 0.0482 \\
\hline A0A3Q2U9L1 & Uncharacterized protein & - & 2 & 1.97347 & 0.0005 \\
\hline A0A1L1RMF4 & Uncharacterized protein & - & 1 & 1.91233 & 0.0064 \\
\hline Q5ZLI2 & $\begin{array}{l}\text { Proteasome subunit alpha } \\
\text { type }\end{array}$ & PSMA3 & 1 & 1.86183 & 0 \\
\hline Q6Q1Q8 & $\begin{array}{l}\text { Mannan-binding lectin } \\
\text { associated serine protease } \\
3\end{array}$ & MASP1 & 1 & 1.8393 & 0 \\
\hline A0A3Q2U7Z1 & Uncharacterized protein & LPXN & 2 & 1.72145 & 0.0416 \\
\hline E1C1Q3 & Uncharacterized protein & SLC29A1 & 1 & 1.64852 & 0 \\
\hline Q9YHD2 & $\begin{array}{l}\text { Nuclear calmodulin- } \\
\text { binding protein } \\
\text { (Fragment) }\end{array}$ & URP; HNRNPUL2 & 1 & 1.63727 & 0.0447 \\
\hline A0A3Q2TUM9 & $\begin{array}{l}\text { C5a anaphylatoxin } \\
\text { chemotactic receptor }\end{array}$ & C5AR1 & 1 & 1.57463 & 0 \\
\hline P68139 & $\begin{array}{l}\text { Actin, alpha skeletal } \\
\text { muscle }\end{array}$ & ACTA1 & 1 & 1.44516 & 0 \\
\hline E1C857 & Tetraspanin & TSPAN6 & 1 & 1.43924 & 0.0315 \\
\hline F1NLE7 & $\begin{array}{l}\text { tRNA-binding domain- } \\
\text { containing protein }\end{array}$ & AIMP1 & 1 & 1.28265 & 0 \\
\hline
\end{tabular}

Table 4 The down-regulated DEPs between DEX and CON groups 


\begin{tabular}{|c|c|c|c|c|c|}
\hline Accession & Description & Gene symbol & $\begin{array}{l}\text { Unique } \\
\text { peptides }\end{array}$ & $\begin{array}{l}\text { DEX vs } \\
\text { CON } \\
\text { (ratio) }\end{array}$ & $\begin{array}{l}\text { DEX vs } \\
\text { CON } \\
(P- \\
\text { value })\end{array}$ \\
\hline E1C3D2 & Septin & SEPT2 & 1 & 0.75954 & 0 \\
\hline E1BWW2 & Uncharacterized protein & $\begin{array}{l}\text { TSG101; } \\
\text { UEVLD }\end{array}$ & 1 & 0.75747 & 0 \\
\hline Q5ZKS2 & Uncharacterized protein & RHOF & 1 & 0.73229 & 0.0152 \\
\hline Q9DF58 & Integrin-linked protein kinase & ILK & 1 & 0.6349 & 0.0156 \\
\hline A5HUM6 & Tenascin X B & TNXB; TN; TNX & 8 & 0.6265 & 0.0001 \\
\hline A0A1D5PMN6 & Uncharacterized protein & KIF1B & 1 & 0.62134 & 0.0186 \\
\hline F1NSM7 & Ovocleidin-116 & MEPE & 3 & 0.62087 & 0.0448 \\
\hline F1N851 & Uncharacterized protein & ENTPD1 & 1 & 0.60771 & 0.0026 \\
\hline P00565 & Creatine kinase M-type & CKM & 3 & 0.58617 & 0.0003 \\
\hline P46157 & Gallinacin-1 alpha & GAL1; AvBD1 & 2 & 0.57304 & 0.0231 \\
\hline Q90631 & Kinectin & KTN1 & 4 & 0.55989 & 0.0284 \\
\hline H9L0D7 & $\begin{array}{l}\text { Wiskott-Aldrich syndrome } \\
\text { protein family member }\end{array}$ & WASF2 & 1 & 0.55391 & 0.0061 \\
\hline Q7SX63 & Heat shock protein 70 & HSPA2 & 2 & 0.5128 & 0.0328 \\
\hline Q5ZHM4 & $\begin{array}{l}\text { CN hydrolase domain- } \\
\text { containing protein }\end{array}$ & VNN1 & 2 & 0.50947 & 0.0447 \\
\hline E1BTI7 & $\begin{array}{l}\text { SMB domain-containing } \\
\text { protein }\end{array}$ & TINAG & 13 & 0.50845 & 0.0299 \\
\hline Q90WD0 & Actin-related protein 3 & ACTR3 & 2 & 0.50512 & 0 \\
\hline Q5G8Y9 & Apolipoprotein D & APOD & 1 & 0.49876 & 0 \\
\hline E1BZN8 & Uncharacterized protein & $\mathrm{F} 12$ & 4 & 0.49585 & 0.0122 \\
\hline P09244 & Tubulin beta-7 chain & TUBB & 1 & 0.49186 & 0.0115 \\
\hline F1C6U4 & $\begin{array}{l}\text { MHC class II antigen beta } \\
\text { chain }\end{array}$ & $\begin{array}{l}\text { LOC101747454; } \\
\text { BLB2 }\end{array}$ & 1 & 0.48491 & 0.0001 \\
\hline A0A1D5P9U9 & Aquaporin-5 & AQP5 & 2 & 0.47223 & 0.0008 \\
\hline Q90XB2 & Surfactant protein A & $\begin{array}{l}\text { SFTPA1; } \\
\text { SFTPA; SFTPA2 }\end{array}$ & 1 & 0.4565 & 0 \\
\hline R4GM71 & $\begin{array}{l}\text { Phosphatidylcholine-sterol } \\
\text { acyltransferase }\end{array}$ & LCAT & 6 & 0.45467 & 0.0035 \\
\hline
\end{tabular}




\begin{tabular}{|c|c|c|c|c|c|}
\hline R4GJX3 & Uncharacterized protein & $\begin{array}{l}\text { LOC770612; } \\
\text { IFITM3 }\end{array}$ & 2 & 0.44714 & 0.0071 \\
\hline R4GKL8 & $\begin{array}{l}\text { C1q domain-containing } \\
\text { protein }\end{array}$ & C1QTNF3 & 2 & 0.44141 & 0.0011 \\
\hline F1NLW7 & $\begin{array}{l}\text { Suppressor of tumorigenicity } \\
14 \text { protein homolog }\end{array}$ & ST14 & 3 & 0.43546 & 0 \\
\hline F1NSA8 & Uncharacterized protein & RAP1A & 1 & 0.41077 & 0.0028 \\
\hline P01994 & Hemoglobin subunit alpha-A & $\begin{array}{l}\text { LOC100858011; } \\
\text { HBAA; HBA1 }\end{array}$ & 6 & 0.40104 & 0.0401 \\
\hline A0A3Q2U3V9 & Uncharacterized protein & LOC100858647 & 6 & 0.39477 & 0.0235 \\
\hline A0A1L1RUW5 & Uncharacterized protein & NMI & 1 & 0.36985 & 0 \\
\hline A0A1D5PIF2 & $\begin{array}{l}\text { LIM domain-containing } \\
\text { protein }\end{array}$ & LIMS1 & 1 & 0.36686 & 0.0169 \\
\hline Q9DER4 & Zona pellucida protein 1 & ZP1 & 2 & 0.36395 & 0 \\
\hline Q04584 & Zyxin & ZYX & 1 & 0.35897 & 0.0001 \\
\hline A0A1D5NXR0 & $\begin{array}{l}\text { VWFD domain-containing } \\
\text { protein }\end{array}$ & - & 3 & 0.3521 & 0.0086 \\
\hline E1BY44 & $\begin{array}{l}\text { TGc domain-containing } \\
\text { protein }\end{array}$ & TGM2 & 7 & 0.32088 & 0.0003 \\
\hline Q8UWG7 & $60 S$ ribosomal protein L6 & RPL6 & 1 & 0.31974 & 0 \\
\hline A0A3Q2U0U0 & $\begin{array}{l}\text { SH3 domain-containing } \\
\text { protein }\end{array}$ & EPS8 & 3 & 0.31449 & 0 \\
\hline A0AOKOPUH6 & Chemerin & RARRES2 & 3 & 0.29516 & 0.0032 \\
\hline A0A1D5PGI9 & BUD13 homolog & BUD13 & 1 & 0.29403 & 0.0457 \\
\hline A0A3Q2TSW8 & Uncharacterized protein & NID2 & 4 & 0.27915 & 0 \\
\hline R4GIW4 & Uncharacterized protein & XPNPEP2 & 2 & 0.27031 & 0.0021 \\
\hline A0A3Q2UIT0 & Tetraspanin & UPK1B & 1 & 0.27014 & 0.0001 \\
\hline A0A1D5NUZ0 & Uncharacterized protein & NAPA & 1 & 0.26364 & 0.0001 \\
\hline F1NVY4 & Uncharacterized protein & GGT1 & 3 & 0.26308 & 0 \\
\hline Q5ZJX9 & $\begin{array}{l}\text { Proteasome subunit alpha } \\
\text { type }\end{array}$ & PSMA5 & 2 & 0.23715 & 0.0003 \\
\hline A0A1D5PNT8 & $\begin{array}{l}\text { VPS10 domain-containing } \\
\text { protein }\end{array}$ & SORT1 & 1 & 0.20383 & 0 \\
\hline F1P2W2 & Uncharacterized protein & ATRN & 5 & 0.19855 & 0.0023 \\
\hline F1P3P3 & Uncharacterized protein & ARHGDIA & 3 & 0.18905 & 0.0004 \\
\hline
\end{tabular}




\begin{tabular}{|c|c|c|c|c|c|}
\hline F1NNF9 & $\begin{array}{l}\text { Ankyrin repeat and kinase } \\
\text { domain containing } 1\end{array}$ & - & 1 & 0.18577 & 0 \\
\hline F1P386 & Uncharacterized protein & CR1L & 1 & 0.18534 & 0 \\
\hline Q90944 & Epiphycan & EPYC & 4 & 0.1505 & 0 \\
\hline A0A2H4C5L 1 & MHC class I antigen & $\mathrm{BF}$ & 1 & 0.14362 & 0 \\
\hline F1NWP1 & Christmas factor & F9 & 6 & 0.14221 & 0 \\
\hline E1BSI4 & Uncharacterized protein & CHMP5 & 1 & 0.1414 & 0 \\
\hline A0A1D5PGT3 & $\begin{array}{l}\text { Brain-specific angiogenesis } \\
\text { inhibitor } 1 \text {-associated protein } \\
2\end{array}$ & BAIAP2 & 2 & 0.12844 & 0 \\
\hline Q9W6V5 & $\begin{array}{l}\text { Receptor-type tyrosine-protein } \\
\text { phosphatase eta }\end{array}$ & PTPRJ & 1 & 0.1273 & 0 \\
\hline B5BSS3 & MHC class I alpha chain 2 & BF2 & 1 & 0.09117 & 0 \\
\hline P87362 & Bleomycin hydrolase & BLMH & 1 & 0.07845 & 0.0004 \\
\hline Q7T2X3 & $\begin{array}{l}\text { Low-density lipoprotein } \\
\text { receptor }\end{array}$ & LDLR & 1 & 0.07034 & 0.0002 \\
\hline F1NPS5 & $\begin{array}{l}\text { Charged multivesicular body } \\
\text { protein } 1 \mathrm{a}\end{array}$ & CHMP1A & 1 & 0.0702 & 0 \\
\hline A0A3Q2U504 & $\begin{array}{l}\text { Vitamin K-dependent protein } \\
\mathrm{S}\end{array}$ & PROS1 & 2 & 0.0574 & 0 \\
\hline Q5ZL65 & Integrin-associated protein & CD47 & 1 & 0.05374 & 0 \\
\hline A0A3Q2U3X0 & $\begin{array}{l}\text { LRRCT domain-containing } \\
\text { protein }\end{array}$ & LOC101750889 & 4 & 0.03605 & 0 \\
\hline A0A1L1RLL0 & $\begin{array}{l}\text { TRASH domain-containing } \\
\text { protein }\end{array}$ & RPL24 & 1 & 0.02835 & 0 \\
\hline A0A1D5P6B0 & $\begin{array}{l}\text { Procollagen C-endopeptidase } \\
\text { enhancer }\end{array}$ & - & 2 & 0.02774 & 0 \\
\hline A0A3Q2TZU8 & Protein tweety homolog & TTYH3 & 2 & 0.00996 & 0.0075 \\
\hline A0A3Q2UHT9 & Uncharacterized protein & EHD4 & 3 & 0.00933 & 0 \\
\hline A0A1L1RZV0 & $\begin{array}{l}\text { Ubiquitin-conjugating enzyme } \\
\text { E2 variant } 2\end{array}$ & UBE2V2 & 1 & 0.00282 & 0 \\
\hline
\end{tabular}

Table 5 The up-regulated DEPs between P8+DEX and DEX groups 


\begin{tabular}{|c|c|c|c|c|c|}
\hline Accession & Description & Gene symbol & $\begin{array}{l}\text { Unique } \\
\text { peptides }\end{array}$ & $\begin{array}{l}\text { P8+DEX } \\
\text { vs DEX } \\
\text { (ratio) }\end{array}$ & $\begin{array}{l}\text { P8+DEX } \\
\text { vs DEX } \\
(P \text { - } \\
\text { value) }\end{array}$ \\
\hline A0A3Q3AJD3 & $\begin{array}{l}\text { WH1 domain-containing } \\
\text { protein }\end{array}$ & - & 1 & 828.76722 & 0 \\
\hline A0A3Q2UHW3 & $\begin{array}{l}\text { Guanine nucleotide- } \\
\text { binding protein subunit } \\
\text { gamma }\end{array}$ & - & 1 & 56.42243 & 0 \\
\hline A0A3Q2TSK8 & $\begin{array}{l}\text { Rho family-interacting cell } \\
\text { polarization regulator } 2\end{array}$ & FAM65B & 1 & 14.49547 & 0 \\
\hline A0M8U0 & $\begin{array}{l}\text { F-actin-capping protein } \\
\text { subunit alpha }\end{array}$ & CAPZA2 & 1 & 14.25679 & 0 \\
\hline A0A3Q2TZA4 & $\begin{array}{l}\text { A2M_recep domain- } \\
\text { containing protein }\end{array}$ & - & 2 & 13.59721 & 0.0242 \\
\hline F1P201 & Uncharacterized protein & VCAM1 & 5 & 6.71103 & 0.0029 \\
\hline F1NL81 & $\begin{array}{l}\text { SCP domain-containing } \\
\text { protein }\end{array}$ & PI16 & 1 & 5.31015 & 0.0118 \\
\hline A0A3Q2U775 & $\begin{array}{l}\text { Ig-like domain-containing } \\
\text { protein }\end{array}$ & - & 1 & 5.30131 & 0 \\
\hline F1P291 & Osteonectin & LOC415258 & 4 & 4.66856 & 0.0243 \\
\hline Q91017 & $\begin{array}{l}\text { Gizzard PTB-associated } \\
\text { splicing factor (Fragment) }\end{array}$ & SFPQ & 2 & 4.03185 & 0 \\
\hline F1P2W2 & Uncharacterized protein & ATRN & 5 & 3.83935 & 0.0119 \\
\hline F1N8W8 & $\begin{array}{l}\text { Serine/threonine-protein } \\
\text { kinase PAK } 3\end{array}$ & PAK3 & 1 & 3.76494 & 0 \\
\hline E1BUA6 & $\begin{array}{l}\mathrm{CN} \text { hydrolase domain- } \\
\text { containing protein }\end{array}$ & VNN1 & 2 & 3.7602 & 0 \\
\hline F1NWN4 & Uncharacterized protein & FBLN2 & 6 & 3.64213 & 0.0429 \\
\hline Q9DER4 & Zona pellucida protein 1 & ZP1 & 2 & 3.49814 & 0 \\
\hline A0A173G7D2 & Mannose-binding lectin & MBL2; MBL & 1 & 3.43387 & 0.0011 \\
\hline R4GKL8 & $\begin{array}{l}\text { C1q domain-containing } \\
\text { protein }\end{array}$ & C1QTNF3 & 2 & 3.32231 & 0 \\
\hline F1NWP1 & Christmas factor & F9 & 6 & 3.27458 & 0.0037 \\
\hline Q5ZJX7 & $\begin{array}{l}\text { Multivesicular body } \\
\text { subunit 12A }\end{array}$ & $\begin{array}{l}\text { FAM125A; } \\
\text { MVB12A }\end{array}$ & 1 & 3.05845 & 0.0001 \\
\hline A0A3Q2U324 & $\begin{array}{l}\text { A2M domain-containing } \\
\text { protein }\end{array}$ & - & 4 & 2.96109 & 0.0087 \\
\hline
\end{tabular}




\begin{tabular}{|c|c|c|c|c|c|}
\hline Q90933 & $\begin{array}{l}\text { Neuron-glia cell adhesion } \\
\text { molecule (Ng-CAM) }\end{array}$ & L1CAM & 14 & 2.88677 & 0.0443 \\
\hline A0A1D5PW36 & Uncharacterized protein & BPIL3 & 1 & 2.82844 & 0.0007 \\
\hline A0A1D5PCD2 & $\begin{array}{l}\text { A2M_recep domain- } \\
\text { containing protein }\end{array}$ & - & 11 & 2.70052 & 0.0007 \\
\hline A0A3Q2U0U0 & $\begin{array}{l}\text { SH3 domain-containing } \\
\text { protein }\end{array}$ & EPS8 & 3 & 2.69614 & 0 \\
\hline F1N851 & Uncharacterized protein & ENTPD1 & 1 & 2.55443 & 0 \\
\hline A0A3Q2U504 & $\begin{array}{l}\text { Vitamin K-dependent } \\
\text { protein S }\end{array}$ & PROS1 & 2 & 2.4876 & 0 \\
\hline Q90WD0 & Actin-related protein 3 & ACTR3 & 2 & 2.36804 & 0 \\
\hline A0A3Q2U3V9 & Uncharacterized protein & LOC100858647 & 6 & 2.3079 & 0.0422 \\
\hline F1NPN5 & $\begin{array}{l}\text { SERPIN domain- } \\
\text { containing protein }\end{array}$ & SPIA3 & 3 & 2.29543 & 0.0116 \\
\hline A0A1D5P7Y2 & Uncharacterized protein & TSPAN13 & 1 & 2.24296 & 0 \\
\hline P23498 & Osteopontin & SPP1 & 1 & 2.14947 & 0.0193 \\
\hline Q5ZJX9 & $\begin{array}{l}\text { Proteasome subunit alpha } \\
\text { type }\end{array}$ & PSMA5 & 2 & 2.0583 & 0.0478 \\
\hline A0A3Q2UBB3 & $\begin{array}{l}\text { Microfibril associated } \\
\text { protein } 2\end{array}$ & - & 1 & 1.93253 & 0.0368 \\
\hline Q90974 & Anti-Muellerian hormone & $\mathrm{AMH}$ & 1 & 1.85467 & 0 \\
\hline Q9DF58 & $\begin{array}{l}\text { Integrin-linked protein } \\
\text { kinase }\end{array}$ & ILK & 1 & 1.82115 & 0.0031 \\
\hline Q2IAL7 & Cathelicidin-2 & CAMP; CATH2 & 1 & 1.74816 & 0.0134 \\
\hline A0A1D5PYR9 & $\begin{array}{l}\text { VWFA domain-containing } \\
\text { protein }\end{array}$ & ITGAD & 3 & 1.73532 & 0.0068 \\
\hline A0A1D5P5T7 & $\begin{array}{l}\text { GP-PDE domain- } \\
\text { containing protein }\end{array}$ & GDPD2 & 1 & 1.69604 & 0.0059 \\
\hline F1NIM0 & $\begin{array}{l}\text { Transmembrane channel- } \\
\text { like protein }\end{array}$ & TMC7 & 1 & 1.49182 & 0.0347 \\
\hline P00565 & Creatine kinase M-type & CKM & 3 & 1.29087 & 0.0194 \\
\hline
\end{tabular}

Table 6 The down-regulated DEPs between P8+DEX and DEX groups 


\begin{tabular}{|c|c|c|c|c|c|}
\hline Accession & Description & Gene symbol & $\begin{array}{l}\text { Unique } \\
\text { peptides }\end{array}$ & $\begin{array}{l}\text { P8+DEX } \\
\text { Vs DEX } \\
\text { (ratio) }\end{array}$ & $\begin{array}{l}\text { P8+DEX } \\
\text { vs DEX } \\
(P- \\
\text { value })\end{array}$ \\
\hline 042351 & Rabaptin-5 & RABEP1 & 1 & 0.75201 & 0 \\
\hline Q90593 & $\begin{array}{l}\text { Endoplasmic reticulum } \\
\text { chaperone BiP }\end{array}$ & HSPA5 & 3 & 0.73616 & 0.0473 \\
\hline E1BWW2 & Uncharacterized protein & TSG101; UEVLD & 1 & 0.72709 & 0 \\
\hline F1P386 & Uncharacterized protein & CR1L & 1 & 0.71003 & 0 \\
\hline P68139 & $\begin{array}{l}\text { Actin, alpha skeletal } \\
\text { muscle }\end{array}$ & ACTA1 & 1 & 0.69197 & 0 \\
\hline F1P4U3 & $\begin{array}{l}\text { Secreted phosphoprotein } \\
2\end{array}$ & SPP2 & 1 & 0.68375 & 0.012 \\
\hline A0A3Q2TXS3 & $\begin{array}{l}\text { Ig-like domain-containing } \\
\text { protein }\end{array}$ & - & 1 & 0.67825 & 0.0036 \\
\hline P21760 & $\begin{array}{l}\text { Extracellular fatty acid- } \\
\text { binding protein }\end{array}$ & $\begin{array}{l}\text { LCN8; P20K; LCN15; } \\
\text { EXFABP }\end{array}$ & 2 & 0.66739 & 0.0496 \\
\hline A0A1L1RUW5 & Uncharacterized protein & $\mathrm{NMI}$ & 1 & 0.65965 & 0.0275 \\
\hline A0A3Q2U7A2 & $\begin{array}{l}\text { Ig-like domain-containing } \\
\text { protein }\end{array}$ & - & 1 & 0.62714 & 0.0159 \\
\hline A0A3Q2UGD4 & $\begin{array}{l}\text { Ig-like domain-containing } \\
\text { protein }\end{array}$ & - & 1 & 0.62172 & 0.0396 \\
\hline E1C1Q3 & Uncharacterized protein & SLC29A1 & 1 & 0.6066 & 0 \\
\hline Q5ZLI2 & $\begin{array}{l}\text { Proteasome subunit } \\
\text { alpha type }\end{array}$ & PSMA3 & 1 & 0.55381 & 0 \\
\hline F1NLE7 & $\begin{array}{l}\text { tRNA-binding domain- } \\
\text { containing protein }\end{array}$ & AIMP1 & 1 & 0.55353 & 0 \\
\hline Q6Q1Q8 & $\begin{array}{l}\text { Mannan-binding lectin } \\
\text { associated serine } \\
\text { protease } 3\end{array}$ & MASP1 & 1 & 0.54368 & 0 \\
\hline F1NNF9 & $\begin{array}{l}\text { Ankyrin repeat and } \\
\text { kinase domain } \\
\text { containing } 1\end{array}$ & - & 1 & 0.53991 & 0 \\
\hline E1C0F3 & Uncharacterized protein & RAB7A & 1 & 0.53376 & 0.0008 \\
\hline Q9BD54 & $\begin{array}{l}\text { MHC class II-associated } \\
\text { invariant chain } \\
\text { (Fragment) }\end{array}$ & CD74 & 1 & 0.51598 & 0 \\
\hline A0A1D5PT95 & Uncharacterized protein & KRAS & 1 & 0.51464 & 0.0327 \\
\hline
\end{tabular}




\begin{tabular}{|c|c|c|c|c|c|}
\hline P01875 & Ig mu chain $\mathrm{C}$ region & - & 16 & 0.51124 & 0.0242 \\
\hline F1NCZ2 & $\begin{array}{l}\text { Rab GDP dissociation } \\
\text { inhibitor }\end{array}$ & GDI1 & 3 & 0.50966 & 0.0131 \\
\hline A0A3Q2U9L1 & Uncharacterized protein & - & 2 & 0.50672 & 0.0005 \\
\hline Q6PW00 & $\begin{array}{l}\text { T-cell receptor T3 delta } \\
\text { chain }\end{array}$ & CD3D & 1 & 0.49022 & 0.0071 \\
\hline E1C857 & Tetraspanin & TSPAN6 & 1 & 0.47527 & 0.003 \\
\hline F1NEB3 & Uncharacterized protein & HABP2 & 5 & 0.44691 & 0.0081 \\
\hline Q8UWG7 & $\begin{array}{l}\text { 60S ribosomal protein } \\
\text { L6 }\end{array}$ & RPL6 & 1 & 0.40712 & 0 \\
\hline F1NQD9 & Radixin & RDX & 1 & 0.39935 & 0.0006 \\
\hline A0A3Q2UDP3 & Uncharacterized protein & DOCK10 & 2 & 0.39916 & 0.0011 \\
\hline F1NDH2 & Angiotensin $1-10$ & AGT & 5 & 0.39399 & 0.036 \\
\hline Q5W9C5 & MHC class I antigen & BF1; HFE & 1 & 0.37324 & 0 \\
\hline E1C007 & $\begin{array}{l}\text { Protein kinase } C \text { and } \\
\text { casein kinase substrate } \\
\text { in neurons protein } 2\end{array}$ & PACSIN2 & 3 & 0.37321 & 0.0161 \\
\hline A5HUM6 & Tenascin X B & TNXB; TN; TNX & 8 & 0.36364 & 0 \\
\hline P07630 & Carbonic anhydrase 2 & CA2 & 4 & 0.36017 & 0.0256 \\
\hline R4GM71 & $\begin{array}{l}\text { Phosphatidylcholine- } \\
\text { sterol acyltransferase }\end{array}$ & LCAT & 6 & 0.3509 & 0.0451 \\
\hline A0A1D5PMA3 & Uncharacterized protein & NELL2 & 1 & 0.34434 & 0.0386 \\
\hline E1C7T9 & Uncharacterized protein & BAIAP2L1 & 4 & 0.34145 & 0.032 \\
\hline A0A3Q2U0N4 & $\begin{array}{l}\text { Ig-like domain-containing } \\
\text { protein }\end{array}$ & - & 1 & 0.33343 & 0.0045 \\
\hline Q5ZL35 & $\begin{array}{l}\text { Arginine and glutamate- } \\
\text { rich protein } 1\end{array}$ & ARGLU1 & 1 & 0.33275 & 0.0193 \\
\hline E1C3Y3 & Tetraspanin & TSPAN8 & 1 & 0.32747 & 0 \\
\hline P00337 & $\begin{array}{l}\text { L-lactate dehydrogenase } \\
\text { B chain }\end{array}$ & LDHB & 2 & 0.29927 & 0.0471 \\
\hline 093410 & Calmodulin & CALM; CALM2 & 8 & 0.27975 & 0.0262 \\
\hline $\mathrm{E} 1 \mathrm{C} 7 \mathrm{C} 1$ & $\begin{array}{l}\text { Complement component } \\
8 \text { subunit beta }\end{array}$ & C8B & 8 & 0.27619 & 0.0044 \\
\hline F1NSD3 & $\begin{array}{l}\text { Ig-like domain-containing } \\
\text { protein }\end{array}$ & - & 1 & 0.27103 & 0.0491 \\
\hline
\end{tabular}




\begin{tabular}{|c|c|c|c|c|c|}
\hline A0A3Q2TUM9 & $\begin{array}{l}\text { C5a anaphylatoxin } \\
\text { chemotactic receptor }\end{array}$ & C5AR1 & 1 & 0.26213 & 0 \\
\hline F1NV09 & $\begin{array}{l}\text { Epithelial cell adhesion } \\
\text { molecule }\end{array}$ & EPCAM & 4 & 0.25783 & 0.0001 \\
\hline A0A1D5PXM8 & $\begin{array}{l}\text { VPS37 C-terminal } \\
\text { domain-containing } \\
\text { protein }\end{array}$ & VPS37C & 1 & 0.25558 & 0.0005 \\
\hline A0A1D5PNT8 & $\begin{array}{l}\text { VPS10 domain- } \\
\text { containing protein }\end{array}$ & SORT1 & 1 & 0.25327 & 0.0005 \\
\hline F1NSM7 & Ovocleidin-116 & MEPE & 3 & 0.25238 & 0.0212 \\
\hline A0A3Q2U540 & $\begin{array}{l}\text { Ig-like domain-containing } \\
\text { protein }\end{array}$ & - & 2 & 0.23225 & 0.0143 \\
\hline A0A1L1RMF4 & Uncharacterized protein & - & 1 & 0.22209 & 0.0005 \\
\hline Q5F442 & Uncharacterized protein & RASA3 & 1 & 0.22128 & 0 \\
\hline Q5F3U5 & Uncharacterized protein & RAP2C & 2 & 0.22044 & 0.0013 \\
\hline F1C6X7 & $\begin{array}{l}\text { MHC class II antigen } \\
\text { alpha chain }\end{array}$ & $\begin{array}{l}\text { B-LA; BLA; HLA- } \\
\text { DRA }\end{array}$ & 2 & 0.21122 & 0.0081 \\
\hline A0A1D5PPP9 & Uncharacterized protein & PTMA & 2 & 0.17915 & 0.0427 \\
\hline R4GLT1 & $\begin{array}{l}\text { Cystatin domain- } \\
\text { containing protein }\end{array}$ & CST3 & 1 & 0.15362 & 0 \\
\hline A0A3Q3АРBЗ & Uncharacterized protein & LOC101748084 & 1 & 0.11231 & 0 \\
\hline A0A3Q2UIJ5 & Uncharacterized protein & LOC769729 & 1 & 0.10447 & 0 \\
\hline F1NIW7 & Cubilin & CUBN & 4 & 0.10149 & 0 \\
\hline Q5F3I1 & $\begin{array}{l}\text { Fibrinogen C-terminal } \\
\text { domain-containing } \\
\text { protein }\end{array}$ & FGL2 & 3 & 0.0853 & 0.0003 \\
\hline A0A3Q2UFJ3 & $\begin{array}{l}\text { Calcium/calmodulin- } \\
\text { dependent protein } \\
\text { kinase }\end{array}$ & CAMK2D & 3 & 0.05437 & 0 \\
\hline F1NUJ7 & $\begin{array}{l}\text { FABP domain-containing } \\
\text { protein }\end{array}$ & FABP6 & 2 & 0.0372 & 0 \\
\hline P35062 & Histone H2A-III & $\begin{array}{l}\text { HIST1H2A3; } \\
\text { LOC427881; } \\
\text { HIST1H2A4L3; } \\
\text { LOC417955 }\end{array}$ & 2 & 0.01549 & 0 \\
\hline
\end{tabular}

\section{Figures}


A

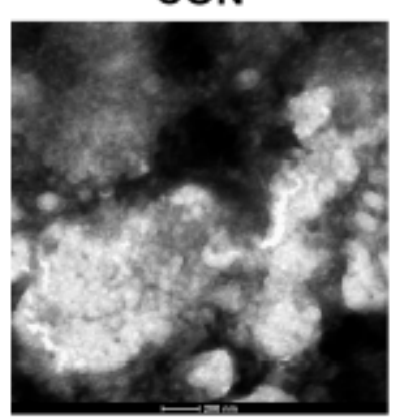

B

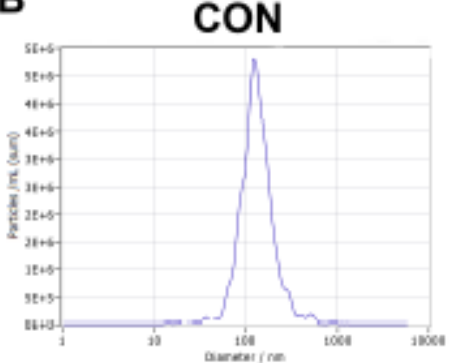

DEX

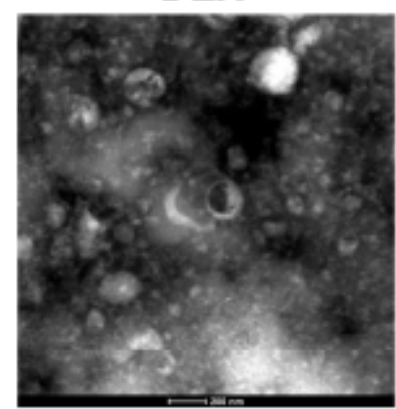

DEX

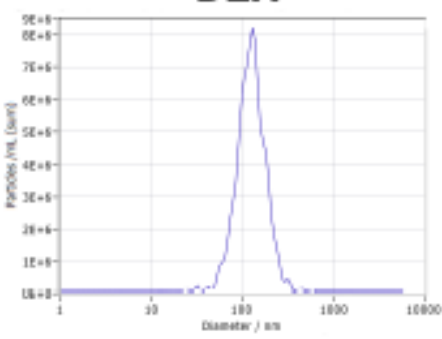

P8+DEX

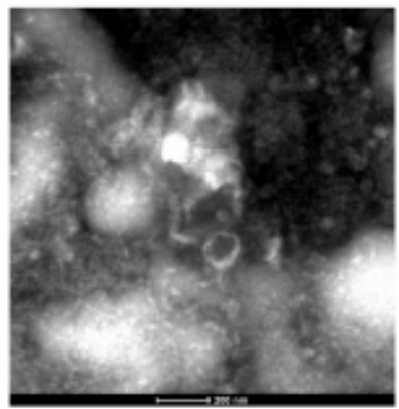

P8+DEX

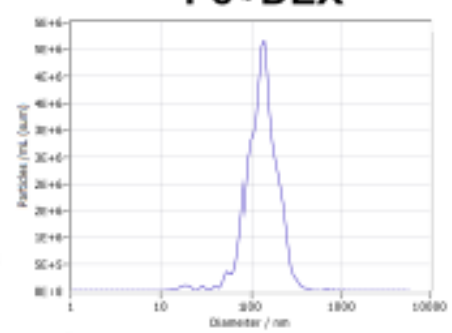

C

\section{CON DEX P8+DEX}

CD63

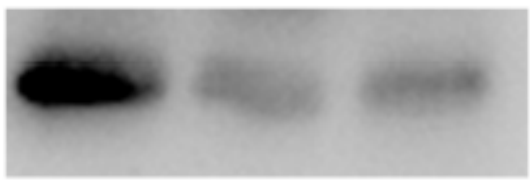

TSG101

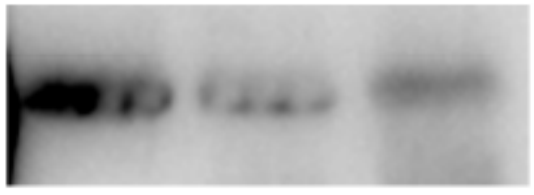

\section{Calnexin}

\section{Figure 1}

Identification of plasmal exosomes of broilers. (A) The observation of exosomes by TEM, bar = $200 \mathrm{~nm}$, (B) NTA of exosomes, (C) Identification of CD63 and TSG101 in plasmal exosomes by WB, Calnexin is a negative control protein were used to validate the quality of our isolation technique. 

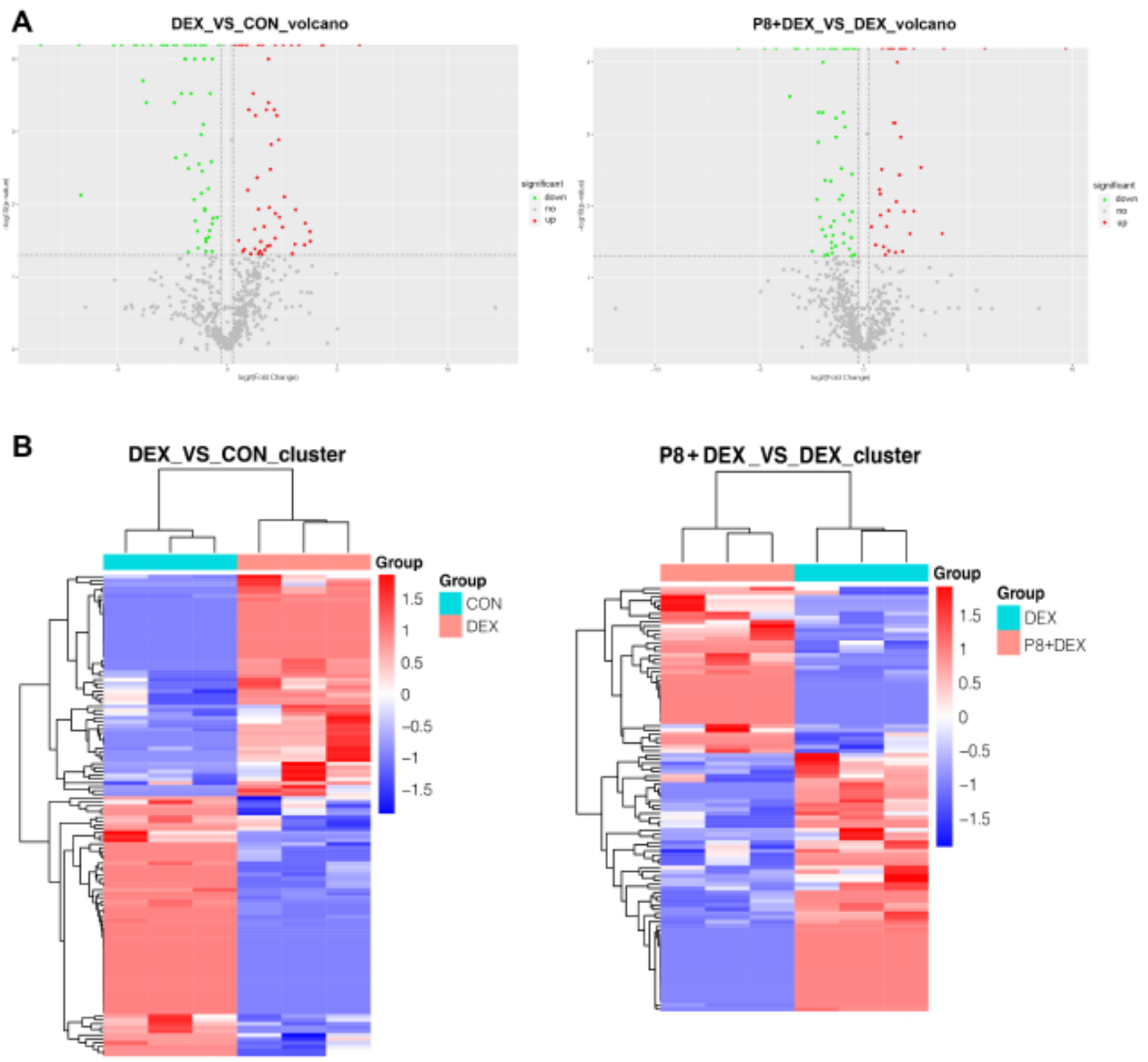

Figure 2

Differentially expressed proteins in plasmal exosomes. (A) Volcano plot, (B) Hierarchical clustering of heatmap. 


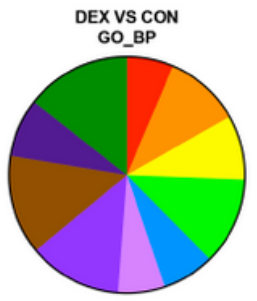

response to stress, 8 crganonitrogen compound metabolic process. 13 protein metaboic proosess, 11 cellilar protein meto 0

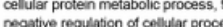
macromolecule metabolic process. 16 ntrogen compound metabolic process, 17 organic substance metabolic process, 18
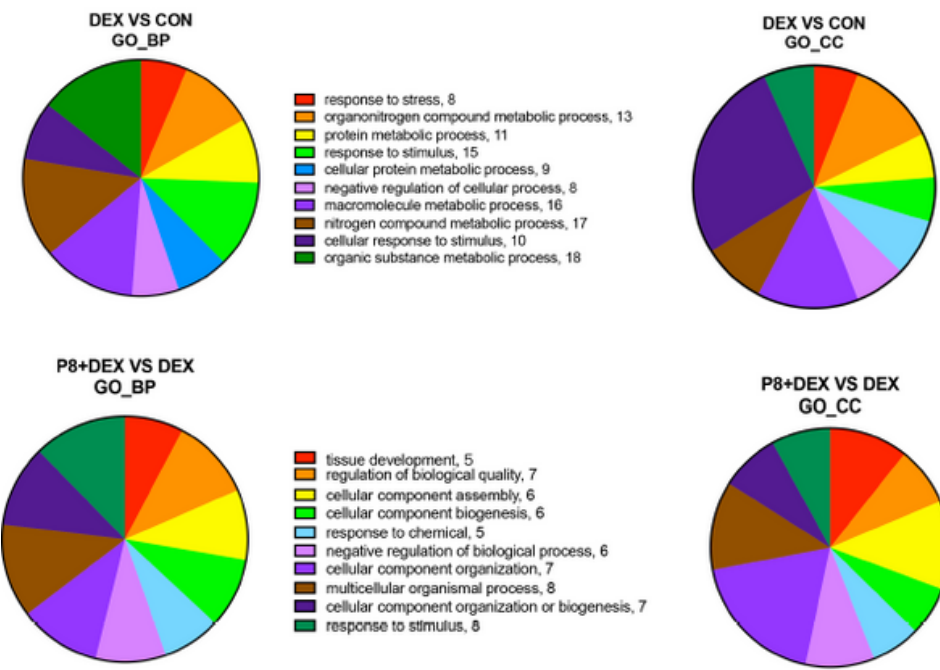

吕 anchoring junction, 7

미 junction, 7

extracellular space,

cell periphery, 9 ,

星 mertoplasm, 16

protein-containing complex

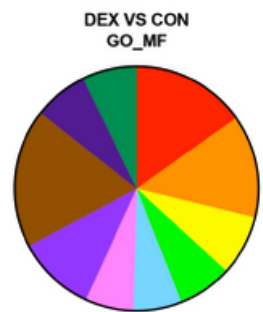

protein binding, 19

carbohydrate derivalive binding purne nucleotide binding. 8 catalytc activity, 13 helerocyclic compound binding, 9
organic cyclic compound binding. 9
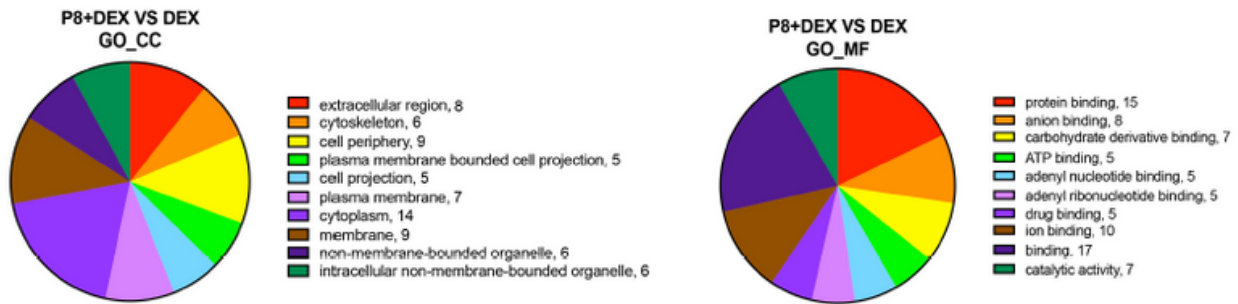

Figure 3

$\mathrm{GO}$ analysis of proteins in plasmal exosomes. BP, biological process; CC, cellular components; $\mathrm{MF}$, molecular function. Pie diagrams show the top 10 enriched GO terms.

DEX_VS_CON_KEGG_Pathway

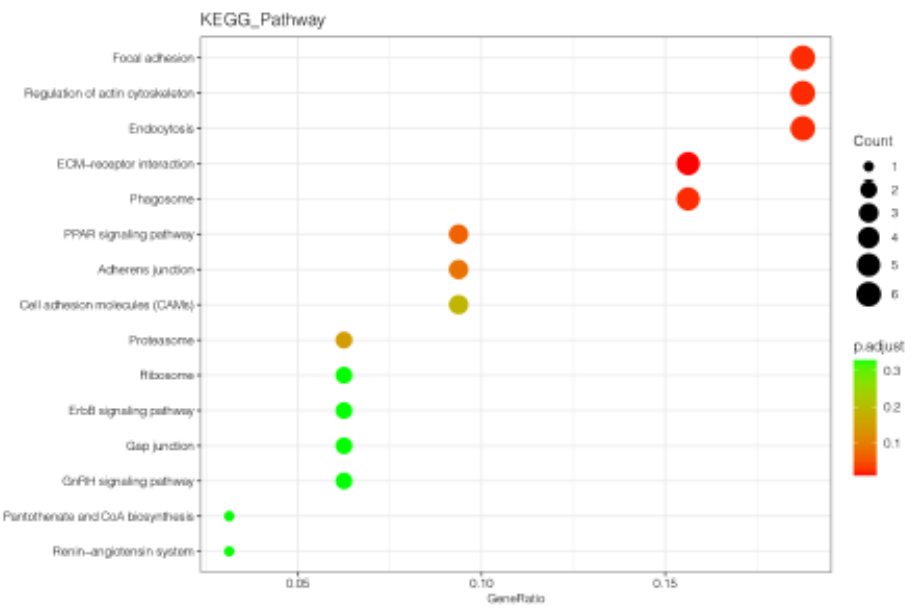

P8+DEX_VS_DEX_KEGG_Pathway

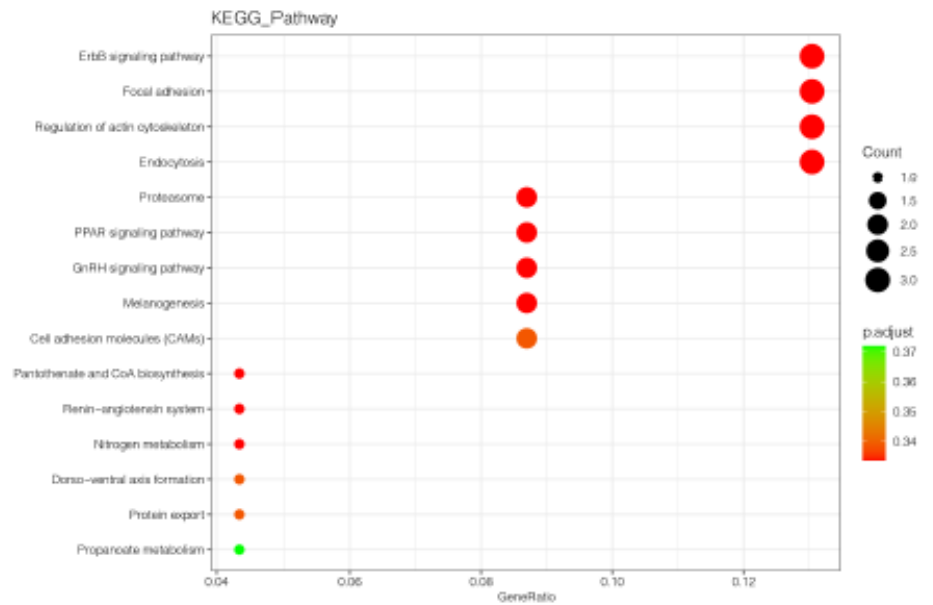

Figure 4

KEGG pathway analysis of proteins in plasmal exosomes. 
Plasma

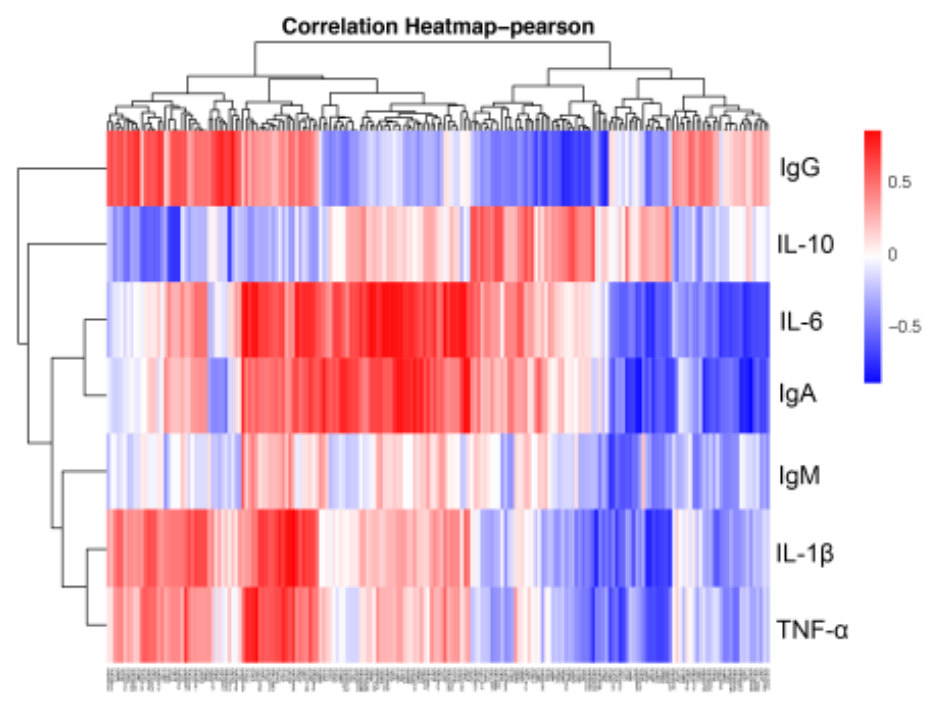

Jejunal mucosa

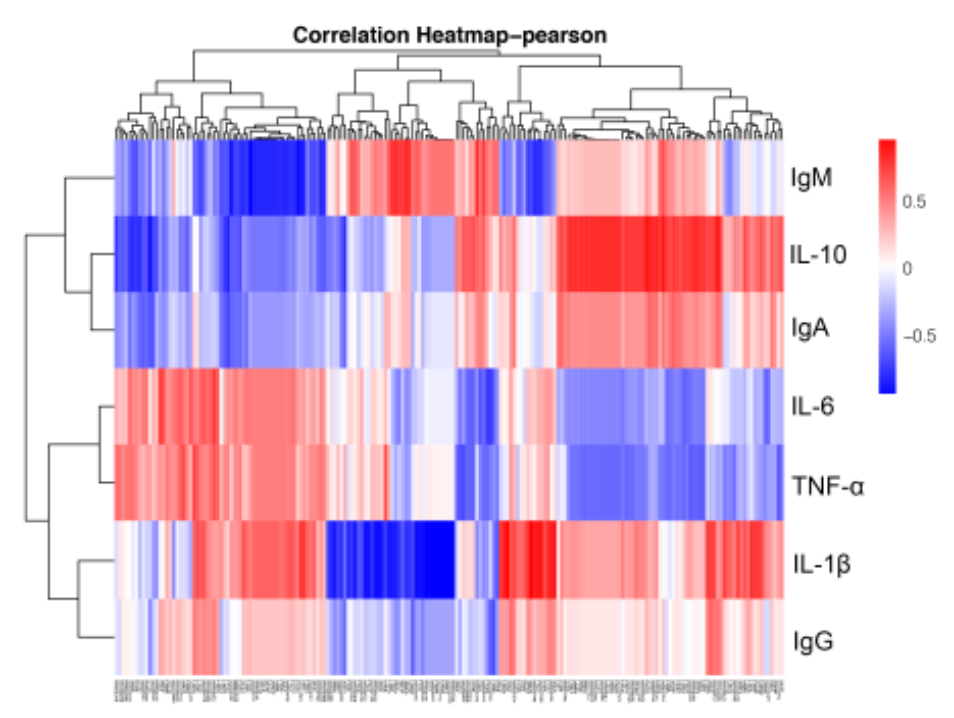

Figure 5

Spearman correlation analyses of exosomal proteins and immune parameters.

\section{Supplementary Files}

This is a list of supplementary files associated with this preprint. Click to download.

- Additionalfile2.xlsx

- Additionalyfile1.docx

- graphabstract.pdf 